\title{
Assessment of Impacts from Water Level Fluctuations on Fish in the Hanford Reach, Columbia River
}

C. D. Becker

D. H. Fickeisen

I. C. Montgomery

that $19+201$

Prepared for the U.S. Depariment of Energy under Contract DE-A C06-76:10 1830

Pacific Northwest Laboratory Operated for the U.S. Department of Energy by Baftelle Memorial Institute 
4. $01:$ i: 1

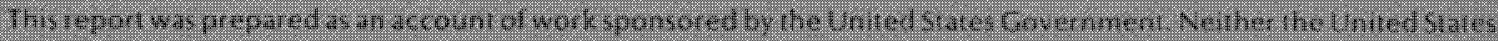

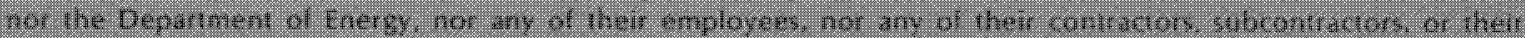

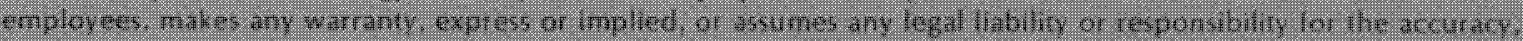

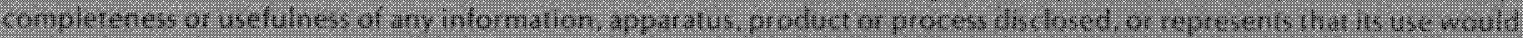

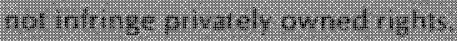

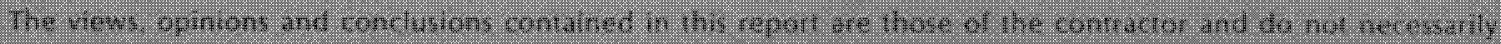

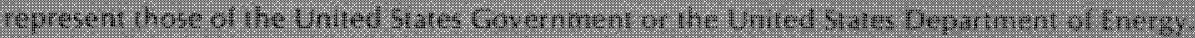

PACEFIC HOKTHWEST LABORATORY

operated by

BATHEL

forthe

UNITIOSTATS DEPARTMEN OF ENEC

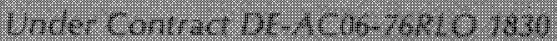

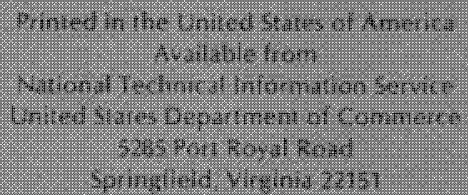

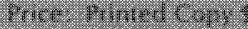

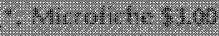

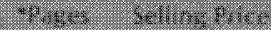

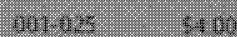

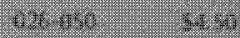

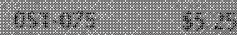

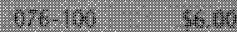

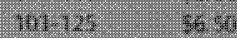

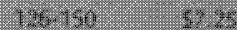

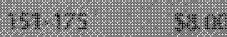

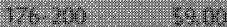

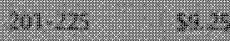

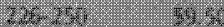

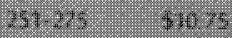

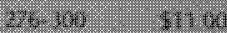




\section{ASSESSMENT OF IMPACTS FROM WATER LEVEL FLUCTUATIONS ON FISH IN THE HANFORD REACH, COLUMBIA RIVER}
C. D. Becker
D. H. Fickeisen
J. C. Montgomery

May 1981

Prepared for

the U.S. Department of Energy

under Contract DE-AC06-76RLO 1830

Pacific Northwest Laboratory Richland, Washington 99352 
SUMMARY

Observations on the effects of water level fluctuations in the Hanford Reach of the Columbia River, Washington, were made in 1976 and 1977. The two years provided contrasting flow regimes: high water and fluctuations of greater magnitude prevailed in 1976; low water and higher temperatures prevailed in 1977. Situations where fish and other aquatic organisms were destroyed by changing water levels were observed and evaluated each year in three study areas: Hanford, F-Area, and White Bluffs sloughs. Losses primarily were due to stranding, entrapment (with or without complete dewatering), and predation. Juvenile fish were more susceptible to entrapment and stranding than were adult fish. Estimates of actual losses were biased and conservative because relatively few fish could be found after each decline of water leve 1 and dewatering.

The most valued species of fish affected by water level fluctuations at Hanford were the anadromus fall chinook salmon (Oncorhynchus tshawytscha) and the resident smallmouth bass (Micropterus dolomieui). Crucial periods for chinook salmon occurred during winter when incubating eggs were in the gravel of the main channel, and before and during seaward migration in the spring when fry were abundant in shoreline zones. The crucial period for smallmouth bass was during spring and early summer when adults were spawning in warmed sloughs and shoreline zones. Chinook salmon and smallmouth bass fry were vulnerable to stranding and entrapment, and smallmouth bass nests were susceptible to exposure and temperature changes resulting from repeated water level fluctuations. Thus, flow manipulation may be crucial to their survival.

The extent to which other species of riverine fish were affected by water level fluctuations depended upon their use of shoreline zones for spawning and rearing young. Few of these relationships are completely known or understood. Most fish fry found stranded or entrapped in 1976 and 1977 consisted of "coarse fish" species, which are abundant and of limited economic value. Loss of young coarse fish from water level fluctuations might not be reflected at the adult 
population level. While some invertebrates lost in shoreline zones may be replaced by survivors from deeper water, those removed are no longer available to higher trophic level consumers. The magnitude of fish and invertebrate losses in shoreline zones may be of little importance to overall ecosystem dynamics. 


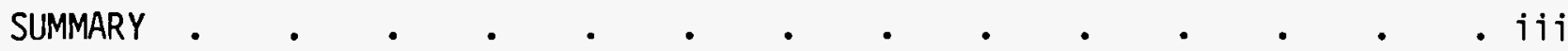

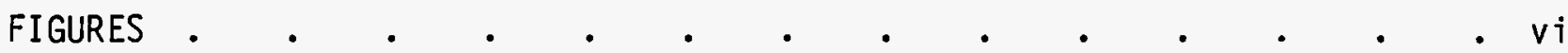

TABLES

INTRODUCTION

Objectives

Definitions

METHODS

LOW-FLOW EXPERIMENT

Results

Hanford Slough

F-Area Slough (North End)

- vij

F-Area Slough (South End)

White Bluffs Slough.

Remarks

ks

RIVER LEVEL FLUCTUATIONS

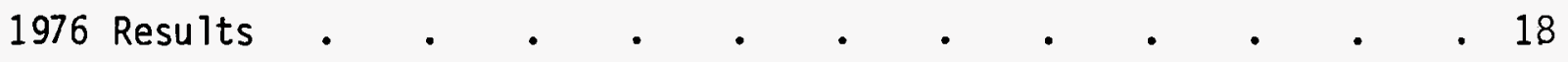

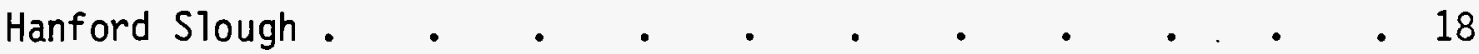

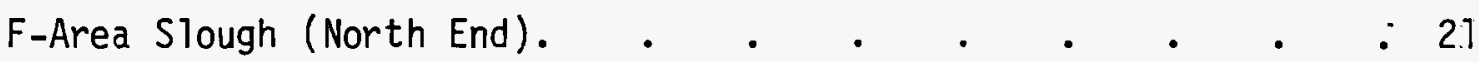

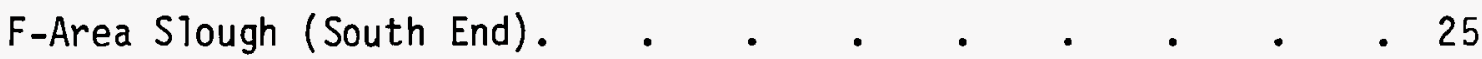

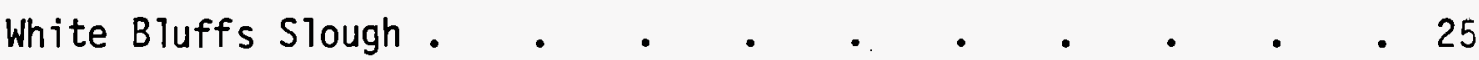

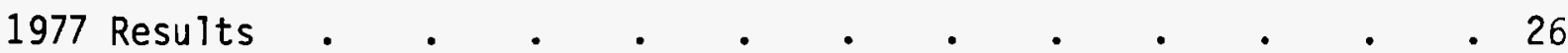

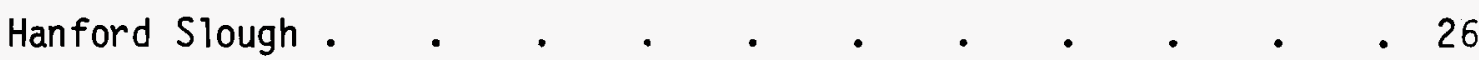

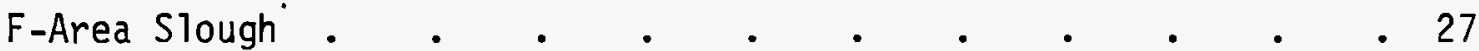

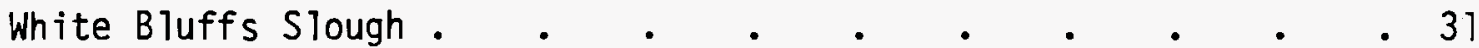

Remarks

BASS TAGGING STUDIES

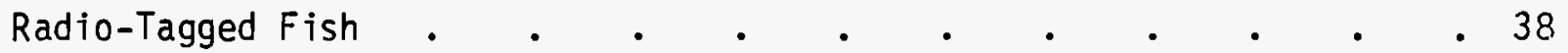

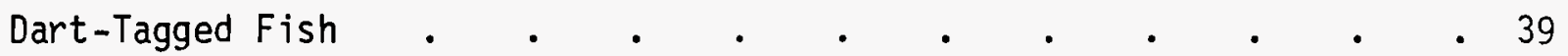

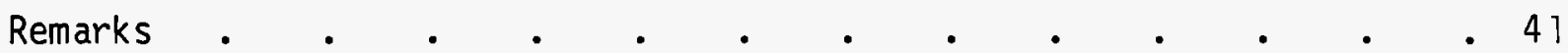

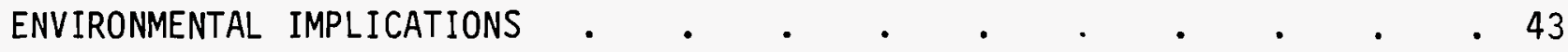

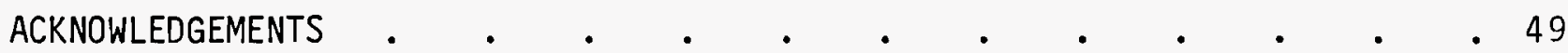

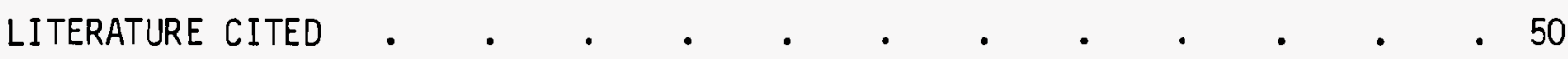




\section{FIGURES}

1 The Mainstem Columbia River, Location of Hydroelectric Dams and Site of the Hanford Reservation Operated by the United States Department of Energy .

2 Typical Electrical Load Pattern Based on Power Demand During One Winter Week in the Pacific Northwest

3 Location of Selected Study Areas for Assessment of Impacts from Water Level Fluctuations on the Hanford Reservation, Mid-Columbia River, Washington State

4 North End of Hanford Slough at High Water (A) and Low Water (B) Stages

5 A Dead Crayfish Found Under Cobblestone During Pond Dewatering, Low Flow Experiment, April 10-11, 1976 • • • • • • . 16

6 Average Week ly Columbia River Flows at Priest Rapids Dam from

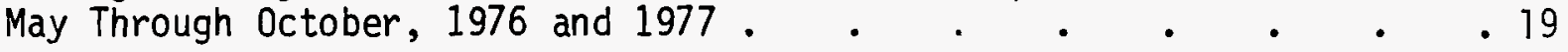

7 Average Week ly Columbia River Temperatures at Priest Rapids Dam from May Through October, 1976 and 1977 . . . . . 20

8 Daily Columbia River Flow Patterns at Priest Rapids Dam from May Through August, 1976 and 1977 . . . . . . . . 21

9 The North End of Hanford Slough Facing South During a Low Water Stage . 23

10 F-Area Slough and Environs During a Summer Period of Low Flow . . 24

11 A Flooded Grassy Area at the Head of F-Area Slough After the April 1977 Spate

12 Chinook Salmon Fry in Mud and Cobblestone Bottom of Dewatered Ponds - 29

13 White Bluffs Slough and Environs During a Summer Period of Low Flow - 30

14 Daily Columbia River Flow Patterns at Priest Rapids Dam During the Spring and Summer of 1960 and 1970 . . . . . . . 33

15 Typical Situations Existing in Pools Subject to Filling During River Level Fluctuations in the Hanford Reach . . . . . 35

16 Typical Situations Existing in Sloughs Subject to Filling During River Leve1 Fluctuations in the Hanford Reach . . . . . 36

17 Movement of Radio-Tagged Smal1mouth Bass at Hanford and White Bluffs Sloughs 


\section{$\underline{\text { TABLES }}$}

1 Common and Scientific Names of Fish Entrapped or Stranded in the Hanford Reach by Water Level Fluctuations, 1976 and 1977 • . 9

2 Aquatic Invertebrate Groups Commonly Entrapped and Dehydrated by Water Level Fluctuations in Shoreline Zones of the Hanford Reach, 1976 and 1977 


\section{INTRODUCTION}

Many rivers are increasingly regulated for power, irrigation, flood control, and industrial and municipal water supplies. Such regulation changes natural flow regimes. With increased interest in renewable sources of electricity and the use of hydroelectric generation for peaking, acute fluctuations in water level are becoming more severe and more widespread. The situation is exemplified by the Columbia River.

Construction of hydroelectric installations and filling of impoundments in recent decades has transformed the mainstem Columbia River into a series of connected storage reservoirs. The reservoir chain extends from Bonneville Dam near the river's out let eastward and northward to the Canadian border. Only one area--the Hanford Reach--remains in an unimpounded, free-flowing condition; it extends about $88 \mathrm{~km}$ from Richland, Washington, upstream to Priest Rapids Dam (Figure 1).

The Hanford Reach is affected by upstream water storage, hydrogeneration, irrigation, and flood control operations that alter river flows. The Hanford Reach is also subject to flow manipulation at an upriver dam, and its daily flow regimes are highly regulated. Future regulatory control is expected to be as great or greater than at present to maximize use of limited water supplies as societal needs increase.

Water passage through turbines at some hydroelectric dams is managed primarily in response to hourly power demand. Some excess water passes over dam spillways during spring spates, resulting in a normal annual period of high flow. Spring spates, however, are now dampened by upstream storage, and volumes of water stored will become greater in future years as turbines are added and reservoir capacity extended (Parametrics, Chapman and Welsh 1979).

Before extensive impoundment, the Columbia River represented a relatively predictable, stable ecosystem in respect to changing flow. The annual runoff would cause a gradual increase in water level over a period of weeks as the winter snow pack melted in the spring; this was followed by a period of sustained high flow during peak runoff and a gradual return to moderate, sustained 


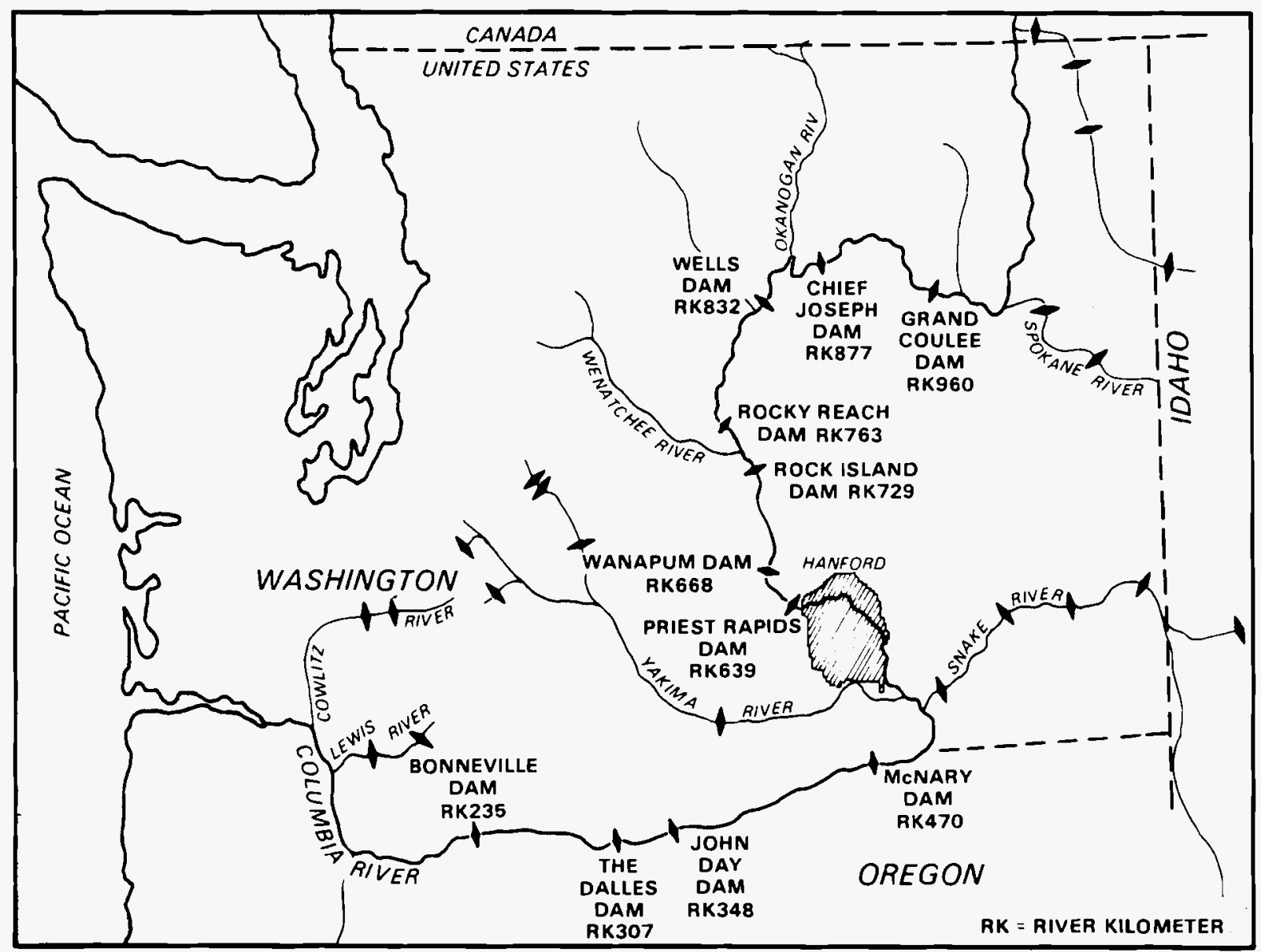

FIGURE 1. The Mainstem Columbia River, Location of Hydroelectric Dams, and Site of the Hanford Reservation Operated by the United States Department of Energy.

flows of summer, fall, and winter. Changes in flow were gradual, with little daily fluctuation in water level. River organisms and riparian plant communities evolved that were adapted to this seasonal change in flow and temperature.

Within the free-flowing Hanford Reach, hydroelectric generation in response to power demand is primarily responsible for rapid changes in water level over a $24-\mathrm{hr}$ period (Figure 2). Such fluctuations may encompass several vertical meters, thereby alternately exposing and inundating large areas of riparian habitat each day. Preliminary observations during the $1970 \mathrm{~s}$ indicated that aquatic organisms in the Hanford Reach were affected by stranding, 
entrapment, and predation as a result of flow manipulation at Priest Rapids Dam. Furthermore, fish were subject to thermal and oxygen stress, and to chronic malnutrition in pools persisting in dewatered areas. These observations occurred during a period when regional power demand approached the limit of existing generating capacity at Columbia River dams. Accordingly, river discharges were being carefully regulated to retain more water in reservoirs when power demand was low and to release more water through turbines when power demand was high.

The observations we now report define several direct impacts on aquatic biota resulting from changes in water level in the Hanford Reach as a result of hydroelectric operation. The observations are more qualitative than quantitative. While the observations reflect impacts on individual organisms or groups of organisms, they do not reflect impacts at the population or ecosystem level. Such effects must be measured quantitatively at considerably higher expenditure of time, manpower, and funds than now available. A complete ecological evaluation must also consider population resiliency and compensation mechanisms inherent in natural populations.

Objectives

The objective of this report is to evaluate how rapid changes in river flow affect aquatic organisms in the Hanford Reach of the Columbia River. Observations are summarized concerning 1) entrapment of fish and invertebrates on April 10 and 11, 1976, a period of minimum low flows; 2) entrapment of fish and invertebrates at White Bluffs, F-Area, and Hanford sloughs during the spring and summers of 1976 and 1977; and 3) movements of tagged smallmouth bass during the summers of 1976 and 1977. Observations and data are interpreted in terms of ecological effects.

Definitions

Dehydration: the disappearance of water from shoreline zones, pools and organisms as a result of dewatering. 


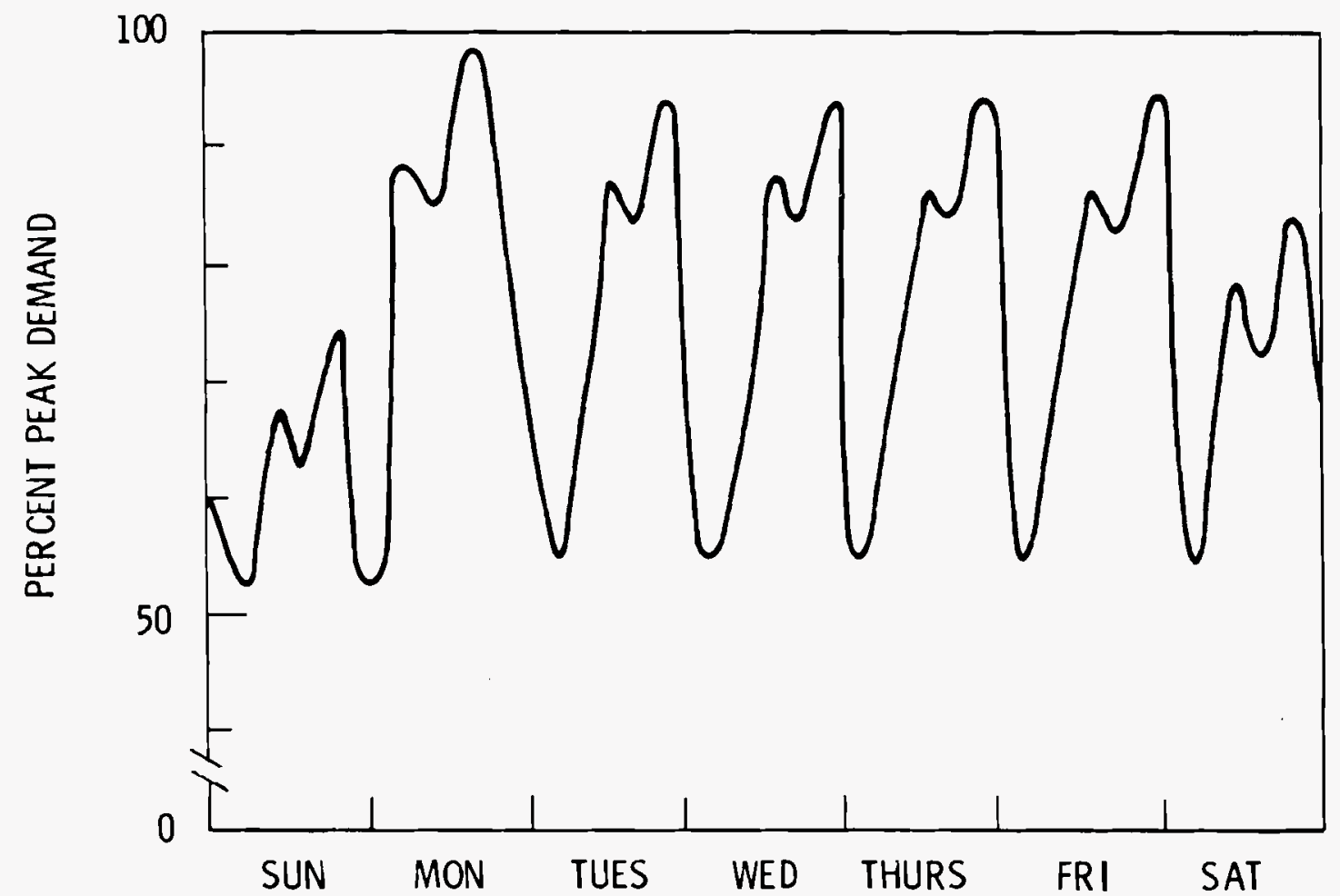

FIGURE 2. Typical Electrical Load Pattern Based on Power Demand During One Winter Week in the Pacific Northwest. (Figure modified from U.S. Army Corps of Engineers 1977.) Note large daily fluctuation during the work week and reduced power demand on week end.

Dewatering: the disappearance of water from an inundated area, pool, pond, or slough as a result of a declining stream leve1, surface runoff, subsurface drainage, or other means.

Drawdown: the intentional reduction of water level in a reservoir or stream that exposes shoreline areas or river bottom.

Entrapment: the isolation of fish and other aquatic organisms from the river in shoreline pools or sloughs that may, or may not, eventually dewater.

Predation: the removal of live, entrapped fish and aquatic organisms from pools, ponds and sloughs by terrestrial vertebrate predators. 
Scavenging: the removal of stranded fish and aquatic organisms from dewatered areas after their death by terrestrial vertebrate scavengers.

Stranding: the exposure of fish and other aquatic organisms to the atmosphere by the disappearance of water from an inundated area, pool, pond or slough after the river level declines.

Shoreline zone: the river margin between low and high flows that is periodically exposed and flooded by fluctuating water levels. 
METHODS

Methods were suitable only for identifying direct impacts and for providing conservative estimates of damage to aquatic organisms. Methods for the Low-Flow Experiment are given by Page (1976).

Walking surveys were initially conducted to identify shoreline areas affected by water level fluctuations on the basis of gradient, conformation, substrate, and presence of potential entrapment areas. Thus, sites were selected to encompass specific terrain features and riparian habitat for impact monitoring. Three sites were selected for study--White Bluffs Slough, F-Area Slough and Hanford Slough (Figure 3). These sites are located on the northeast corner of the U.S. Department of Energy's Hanford Reservation. Human access has been restricted in this area for nearly 40 years. The sites are also recognized spawning sites for smalimouth bass (Micropterus dolomieui), a valued resident sport fish. In addition, large numbers of chinook salmon (Oncorhynchus tshawytscha) fry and fingerlings temporarily inhabited shoreline zones at the sites annually from mid-March to June after emergence and while migrating seaward.

Mortalities of aquatic organisms were documented photographically. Dewatered areas, entrapment ponds, dehydrated areas, and evidence of predation by birds and mammals were also photographed.

Surveys with electroshockers were conducted to determine the species and number of fish in smaller isolated ponds and pools that later were dewatered by drainage. Organisms in larger entrapment ponds that resisted dewatering were collected by trapnet, beach seine, and crayfish traps. Recently dewatered ponds were examined visually to determine the species and estimate the number of fish lost. Predation was inferred from predator tracks on the margin of isolated pools, and scavenging by tracks in recently dewatered areas.

Movement and behavior of adult smallmouth bass during spring spawning periods were examined by attaching radiotelemetry tags, which were subsequently monitored from a mobile receiving station, and by dart tags. Spawning success, residence time in study areas, entrapment, and escape was recorded in relation to daily, weekly and annual changes in river water level. 


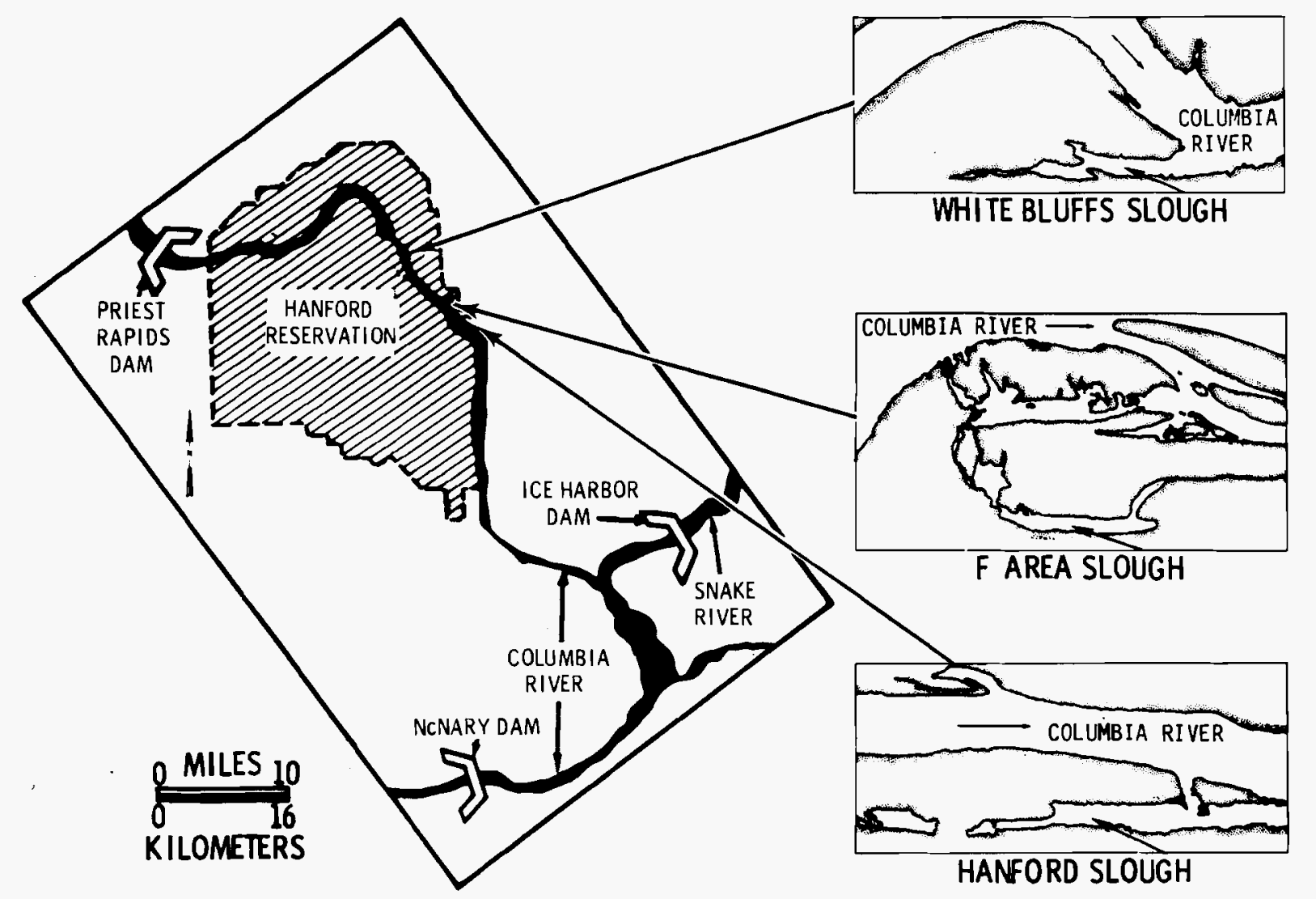

FIGURE 3. Location of Selected Study Areas for Assessment of Impacts from Water Level Fluctuations on The Hanford Reservation, Mid-Columbia River, Washington State.

Radiotelemetry equipment was fabricated by the Bioelectronics Laboratory at the University of Minnesota (Tester and Siniff 1976). The receiver could distinguish among 100 different crystal-tuned radiotags from a frequency of 53.000 to $53.999 \mathrm{MHz}$. Directional antennas were mounted in the back of a pickup truck and in a boat. Transmitters measured $50.8 \mathrm{~mm}$ by $15.0 \mathrm{~mm}$, weighed $19.3 \mathrm{gm}$ when dry, and were encased in epoxy resin with a projecting, $30 \mathrm{~mm}$ long teflon-coated antenna. Radiotags were fastened to adult bass by inserting two attachment cables through the dorsal musculature of the fish (Montgomery and Fickeisen 1978; Montgomery, Fickeisen and Becker 1980).

Radiotagged bass were monitored at least twice weekly, and fish location at each "siting" was marked on a map. This allowed calculation of minimum movement between sitings. 
Movement of dart-tagged bass was monitored by subsequent recovery of tags from local fishermen. Dart-tagged bass entrapped by falling water levels in ponds were monitored by angling and seining, and released at the capture site.

Common names of aquatic organisms are used in the text; Tables 1 and 2 list the common and scientific names of organisms encountered. Common and scientific names of fish are those recommended by the American Fisheries Society (Robins et al. 1980). Dominant species of phytoplankton, zooplankton, benthic invertebrates, and fish in the Hanford Reach are known and have been characterized in relation to the ir seasonal abundance (Battelle, Pacific Northwest Laboratories 1976). 
TABLE 1. Cormon and Scientific Names of Fish Entrapped or Stranded in the Hanford Reach by Water Leve 1

Fluctuations, 1976 and 1977 (a)

\begin{tabular}{|c|c|c|}
\hline Family & Common name & Scientific Name \\
\hline Salmon idae & $\begin{array}{l}\text { coho salmon } \\
\text { chinook salmon } \\
\text { **steelhead trout } \\
\text { mountain whitefish }\end{array}$ & $\begin{array}{l}\text { Oncorhynchus kisutch (Walbaum) } \\
\text { O. tshawytscha (Walbaum) } \\
\text { Salmo gairdner } i \text { (Richardson) } \\
\text { Prosopium williamsoni (Girard) }\end{array}$ \\
\hline Centrarchidae & $\begin{array}{l}\text { *pumpk inseed } \\
\text { *bluegil1 } \\
\text { * smallmouth bass } \\
\text { * largemouth bass } \\
\text { *white crappie } \\
\text { black crappie }\end{array}$ & 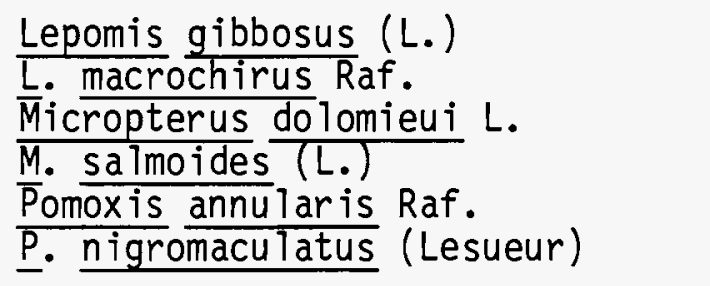 \\
\hline Cyprinidae & $\begin{array}{l}\text { chise lmouth } \\
\text { *common carp } \\
\text { *peamouth } \\
\text { *northern squawfish } \\
\text { *redside shiner }\end{array}$ & $\begin{array}{l}\frac{\text { Acrocheilus alutaceus Agassiz and }}{\text { Pickering }} \\
\text { Cyprinus } \\
\frac{\text { Mylocheilus }}{\text { Ptychocheilus }} \text { caurinus (Richardson) } \\
\frac{\text { oregonensis }}{\text { (Richardson })} \\
\frac{\text { Richardsonius }}{\text { (Richardson) }} \text { balteatus }\end{array}$ \\
\hline Percidae & $\begin{array}{l}\text { yellow perch } \\
\text { **alleye }\end{array}$ & $\begin{array}{l}\text { Perca flavescens (Mitchi11) } \\
\text { Stizostedion vitreum } \\
\text { vitreum (Mitchi11) }\end{array}$ \\
\hline Ictaluridae & $\begin{array}{l}\text { *black bullhead } \\
\text { yellow bullhead } \\
\text { brown bullhead } \\
\text { channel catfish }\end{array}$ & $\begin{array}{l}\frac{\text { Ictalurus melas (Raf.) }}{\text { I. }} \text { natalis (Lesueur) } \\
\bar{I} \cdot \frac{\text { nebuTosus (Lesueur) }}{\text { I. }} \text { punctatus (Raf.) }\end{array}$ \\
\hline Catostomidae & $\begin{array}{l}\text { bridge lip sucker } \\
\text { *largescale sucker } \\
\text { *prickly sculpin }\end{array}$ & $\begin{array}{l}\frac{\text { Catostomus }}{\text { and Eigenmann) }} \frac{\text { columbianus (Eigenmann }}{\text { C. macrocheilus Girard }} \\
\text { Cottus asper Richardson }\end{array}$ \\
\hline Gasterosteidae & *threespine stickle & Gasterosteus aculeatus L. \\
\hline
\end{tabular}


TABLE 2. Aquatic Invertebrate Groups Commonly Entrapped and Dehydrated by Water Level Fluctuations in Shoreline Zones, Hanford Reach, 1976 and $1977(a)$

Common Name

Crayfish

Freshwater leeches

Freshwater snails

Freshwater clams

Anne lids

Mayflies

Dragonflies

Damse If lies

Water boatmen

Back swimmers

Giant water bugs

Cadd isf 1 ies

Predaceous water beet les

Water scavenge beetles

Midge Tarvae
Scientific Name or Classification

Pacifasticus leniusculus

(Hirudinea)

(Gastropoda)

(Pelecypoda)

(Lumbricu Tidae)

(Ephemeroptera)

(Anisoptera)

(Zygoptera)

(Hemiptera: Corixidae)

(Hemiptera: Notonectidae)

(Hemiptera: Belostomatidae)

(Trichoptera)

(Coleoptera: Dytiscidae)

(Coleoptera: Hydrophilidae)

(Diptera: Chironomidae)

(a) No detailed survey of stranded invertebrates was made with the aim of producing a complete taxonomic list of organisms. This table lists the general categories of some common macroinvertebrates observed. 


\section{LOW-FLOW EXPERIMENT}

Effects of a rapid, controlled decline in water level at the three study sites was observed on April 10 and 11, 1976. Washington Public Power Supply System (WPPSS) had arranged for a brief period of the legal minimum flow release from Priest Rapids Dam to examine water levels and current patterns at the intake of a new power plant (WNP-2), then under construction. Observations to detect fish stranding, particularly of juvenile chinook salmon, were made by PNL at other locations in the Hanford Area as water levels declined in a co-operative effort (Page 1976).

Our study on effects of water level fluctuations in the Hanford Reach had entered its initial phase. Observations were made in the three study areas at the time of the low-flow test to identify environmental features associated with an extreme decline in water level. A reduction in flow from about 95,000 to $36,000 \mathrm{cfs}\left(2690\right.$ to $1020 \mathrm{~m}^{3} / \mathrm{sec}$ ) was initiated at Priest Rapids Dam on the midnight of April 9. Falling water levels occurred downstream at the study sites in early morning before daylight on April 10. In an effort to minimize fish stranding and entrapment, the intended drop was not to exceed one vertical foot per hour at Priest Rapids Dam

\section{Results}

Hanford Slough

Several shallow ponds appeared at the north end of Hanford Slough (Figure 4) as the water level receded during the morning, April 10. The largest pool (about $1 \mathrm{~m}$ deep) continued to drain via a shallow stream during the low-flow period, which indicated bank storage and seepage of water from surrounding areas. Adult fish were trapped in the pool, but the shallow channel prevented escape to the rapidly receding river. Four adult fish (a largemouth bass, a white crappie, a largescale sucker, and a threespine stick leback) attempted to negotiate the channel but stranded and died. Smaller isolated pools contained chinook salmon fry, prickly sculpin and an adult smallmouth bass. The pools drained and decreased in size throughout the day. All fish 

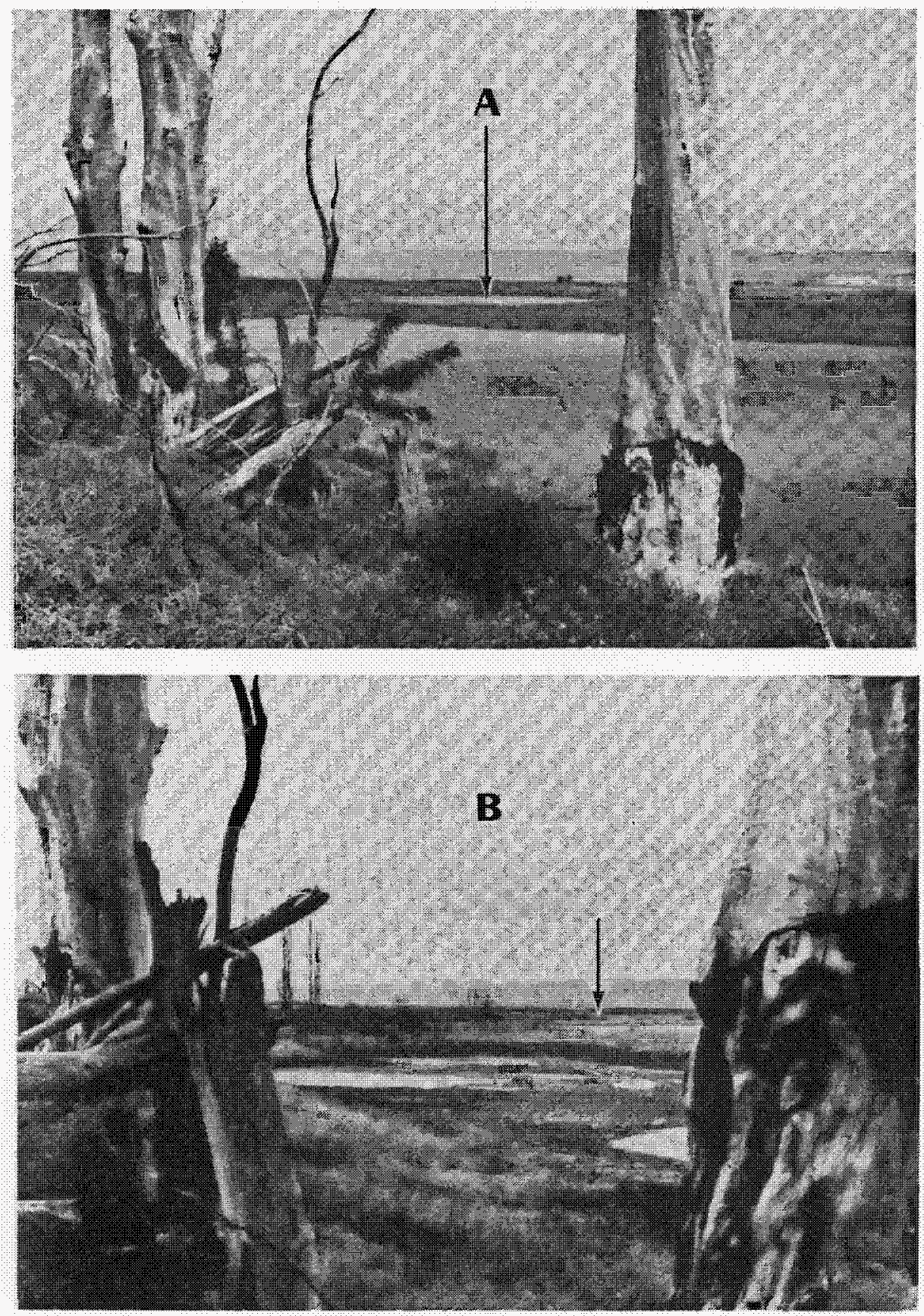

FIGURE 4. North End of Hanford Slough at High Water (A) and Low Water (B) Stages. Note numerous entrapment ponds and puddles. Larger ponds did not completely drain and served as refuges for larger fish. Smaller puddles usually dewatered within $24 \mathrm{hr}$ and trapped fish fry. The large pond (arrow) received river water only during the annual spring spate, but fish were usually entrapped and isolated the rest of the year. 
presumably perished either directly from pool dewatering or indirectly from solar warming and predation.

An estimated 1,000 to 2,000 chinook fry were entrapped in several small pools near the upper end of Hanford Slough. All fry presumably perished. The pools completely drained by morning, April 11, but no stranded chinook fry were found. Since animal tracks (coyote, mink, great blue heron, killdeer, and sandpiper) covered the dewatered area, missing fry were presumably either scavenged or hidden in mud and gravel interstices.

Death from thermal and oxygen stress probably occurred for many small fish prior to complete dewatering of pools. Temperatures in shallow ponds increased from the ambient river level of $6^{\circ} \mathrm{C}$ to $20^{\circ}-25^{\circ} \mathrm{C}$ by mid-afternoon, approaching or exceeding the $21.5^{\circ} \mathrm{C}$ upper thermal tolerance limit of juvenile chinook acclimated at $6^{\circ} \mathrm{C}$ (Brett 1952). Since ambient air temperatures were relatively cool and skies were partially cloudy, the temperature rise in isolated pools was probably less than would occur on a warm and sunny day.

Crayfish were present in several pools, and some were stranded as water levels dropped. Fate of these organisms is unknown, although predation probably took its toll. Survival of some crayfish may be prolonged by moist conditions beneath rocks and in mud. The crayfish is more resistant to warm water temperatures than are juvenile salmonids, but less resistant than either largemouth bass or brown bullhead (Becker, Genoway and Merrill 1975).

\section{F-Area Slough (North End)}

A land bridge connecting the shore to a large island was formed at the upper end of the F-area slough by the afternoon of April 10. The channel became an isolated water body by mid-morning. At normal river flows, the upper and of the channel contains many coves and large ponds with mud and cobblestone substrates. Since the area was rapidly exposed due to the relatively gradual shoreline slope, numerous small puddles resulted that measured about $1 \mathrm{~m}^{2}$.

Numerous chinook salmon fry, cyprinid fry, crayfish and aquatic insect larvae, and some largemouth bass fry and threespine stick leback, were trapped in the small puddles. By the morning of April 11, most of the ponds had dewatered, and an estimated $90 \%$ to $95 \%$ of the organisms died. However, on ly a 
few dead organisms were subsequently found. Apparently, many small fish entered moist mud in rock interstices as the water level dropped. Also, tracks indicated that terrestrial scavengers (coyotes, birds, racoons) were active and probably removed many fish.

We estimate that several thousand salmon and cyprinid fry and several hundred crayfish perished in the area adjacent to the slough during the lowflow test. In support of this estimate, 14 salmonid fry, 9 cyprinid fry, and 2 crayfish were later found beneath the edges of one rock measuring about 28 by $30 \mathrm{~cm}$.

An estimated 10,000 fry were observed trapped in two larger ponds, each about $50 \mathrm{~m}^{2}$. The fish were too small and numerous for complete positive field identification, but most were probably mountain whitefish. The ponds were dewatered on the morning of April 11, and no fry were found. This was probably due to bird predation (abundant tracks) and mixing of fish with mud as the last water drained.

One large pond, a backwater area of the main river $\left(\simeq 500 \mathrm{~m}^{2}\right.$ and 1 to $2 \mathrm{~m}$ deep), was isolated as water receded. Several adult smallmouth bass were trapped. All fish apparently survived because the pond retained water until flows were increased on the afternoon of April 11. Salmonid, cyprinid, and whitefish fry were seen along the pond's margin, but no estimate of their number was made. Some adult bass probably preyed on the fry.

\section{F-Area Slough (South End)}

A large pond in the south end of F-Area Slough was also isolated from the river. It drained slowly via a small stream, but the water level dropped only a few centimeters. Tumbleweeds blown into the pond provided cover for salmonid fry and other small fish. The period of minimal river flow probably had little effect on organisms temporarily retained in the pond.

The drainage channel eventually separated into two branches. One branch dried, isolating several puddles that averaged less than $1 \mathrm{~m}^{2}$ in area. All were dry by the morning of April 11. Several crayfish, aquatic insects, and ten salmon fry were found dead. Tracks indicated heavy scavenging by mammals and birds. Some small fish were found hidden under rocks. 


\section{White Bluffs Slough}

Three types of pond entrapment occurred in White Bluffs Slough, depending upon whether the ponds were located at the the north end, the south end, or at the southeast shoreline.

The north end contained a series of ponds measuring 5 to $20 \mathrm{~m}$ wide and 30 to $40 \mathrm{~cm}$ deep. The ponds were connected by shallow channels about $1 \mathrm{~m}$ wide and $20 \mathrm{~cm}$ deep. Pond features ranged from mud bottom with steep, grassy edges to river cobble bottom and gently sloping edges. Parts of the ponds and channels were choked with tumbleweeds. Salmonid fry, cyprinid fry, and caddisfly larvae were present. The ponds did not dehydrate on Apri1 10 or 11, and temperatures remained below lethal limits until water levels increased. Consequently, little mortality was observed.

The south end contained a pair of larger, deeper ponds connected by a channel 40 to $50 \mathrm{~cm}$ deep and fed by intragravel seepage or springs. These drained via a shallow channel leading to the main slough. Adult carp, smal1mouth bass, 1argemouth bass, largescale and bridgelip suckers, and chinook salmon fry were present. No mortality of adult fish occurred because ample water depth and favorable temperature were maintained. Adult smallmouth bass were observed feeding on salmon fry. Although the drainage channel was too shallow for adult fish to pass, several thousand salmon fry were swimming in or near the channe 1 .

Numerous ponds on the southeast shoreline zone were shallow, had mud and cobble bottoms, and ranged from about one to severa $1 \mathrm{~m}^{2}$ in area. Many ponds contained chinook salmon fry, cyprinid fry, redside shiner and chironomid (midge fly) larvae. By the afternoon of April 10, pond temperatures reached $20^{\circ} \mathrm{C}$, approaching the lethal limit for juvenile salmonids.

One pond ( 15 by $6 \mathrm{~m}$ diameter) contained an estimated 1,000 to 2,000 chinook salmon fry. By the morning of Apri1 11, most ponds were dewatered and tracks of mammal and bird predators were abundant. Examination of bottom mud revealed no dead fish, but one dead crayfish was found near an exposed cobblestone (Figure 5 ). 


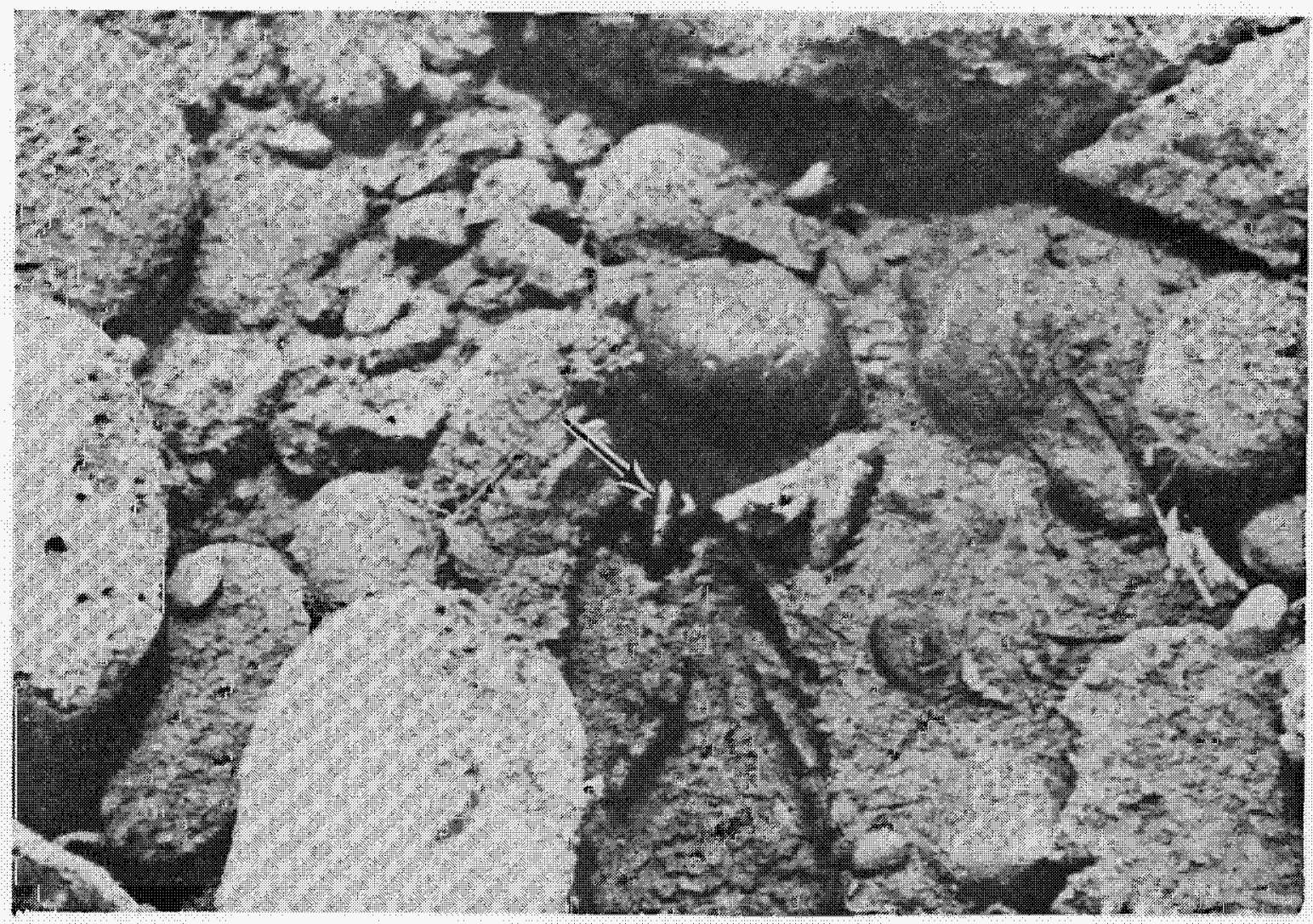

FIGURE 5. A Dead Crayfish Found Under Cobblestone During Pond Dewatering, Low-Flow Experiment, Apri1 10-11, 1976.

$\underline{\text { Remarks }}$

Shoreline zones in the Hanford Reach are productive ecological areas. They are inhabited during spring by fry of many fish species, including smal1mouth bass, largemouth bass, chinook salmon, and numerous species of aquatic invertebrates. The low-flow experiment arranged by WPPSS in Apri1, 1976, caused Columbia River water levels to drop rapidly over a 4-hr period from about 95,000 cfs $\left(2690 \mathrm{~m}^{3} / \mathrm{sec}\right)$ to minimum legal levels of 36,000 cfs (1020 $\left.\mathrm{m}^{3} / \mathrm{sec}\right)$. The water stayed at that stage for about $36 \mathrm{hr}$, and then increased to near the former flow level. Test conditions were unique. An abrupt decline in water level to minimum levels within a short period of time would occur rarely under normal hydroelectric generating conditions.

Our observations in three selected on-site areas led to the following conclusions: 
1) Losses of mobile, aquatic organisms such as fish are related largely to the number, size, substrates, and drainage features of entrapment ponds left by the receding water (i.e., the shoreline zone topography).

2) Adult fish may escape by either following the receding water of the main river channel outward, or by choosing deeper pools that do not drain comp letely.

3) Juvenile fish are more susceptible to entrapment than are adult fish. Juveniles linger in shallow water areas that first become isolated and then warmed and dewatered.

4) Observations after dewatering do not portray the extent of fish loss because dead individuals cannot be accurately enumerated. They enter mud and penetrate beneath cobblestones as the water recedes, or are taken by predators or scavengers. Since only a few fish are found by observers, estimates of losses are strongly biased and highly conservative.

5) Sma11, shallow ponds in the Hanford area may drain rapidly because the underlying substrate consists largely of permeable river gravel. Drainage is rapid if the bottom is above the surface of the nearby river.

6) Large, deep ponds usually drain slowly or incompletely because they are supplied by drainage water from bank storage or from springs, their bottom may extend below the surface of the nearby river, and/or the underlying substrate is less permeable.

7) Entrapped fish may be exposed to low oxygen and high temperature stress before complete dewatering of smaller ponds takes place. The fish are also subject to predation or scavenging.

8) Since fry are more susceptible to stranding than are adult fish, the greatest impact from a major decline in river flow would occur when young fish are at peak abundance, usually the spring and summer. 


\section{RIVER LEVEL FLUCTUATIONS}

High flows characterized the Columbia River during the spring and summer of 1976. Flows did not decline to usual summer levels until late September. In contrast, the Pacific Northwest experienced a drought in 1977, and water entering Columbia River tributaries upstream from Hanford was reduced below typical summer levels. The contrasting flow regimes past Priest Rapids Dam are shown in Figure 6. Low-flow years are accompanied by significant warming of Columbia River water compared to high-flow years (Figure 7 ).

\section{Results}

Planning was the major effort in the initial year. However, ten walking surveys to define impacts from water level fluctuations were conducted between April and October 5 at Hanford, F-Area, and White Bluffs sloughs. Water level fluctuations were well defined despite the relatively high discharges and spills at Priest Rapids Dam. In fact, water level fluctuations proved to be more abrupt and of greater magnitude in 1976, as in 1977, a low-flow year. (Figure 8). A number of impacts on aquatic organisms in shoreline areas were identified in association with fluctuating changes in river flow.

Since the three study sites were known spawning areas for smallmouth bass, we hypothesized that spawning and incubation of smallmouth bass eggs would be affected by fluctuating water levels. Seven adult smallmouth bass were radiotagged at White Bluffs Slough by late June. Subsequent monitoring showed that the use of radiotags to locate spawning smallmouth bass was feasible. Monitoring also provided information on bass entrapment in large ponds, bass nesting sites, and smallmouth bass residence-time in ponds and sloughs.

\section{Hanford Slough}

Water levels fell in August 1976 after the peak summer flows. A large pond was disconnected at the northern end of the main slough on September 15. Yearling largemouth bass, bluegill, threespine stickleback, black crappie, yellow bullhead and carp were trapped in a 30 by $0.5 \mathrm{~m}$-area connecting the slough and pond. The area completely dried by 0ctober 5 . 


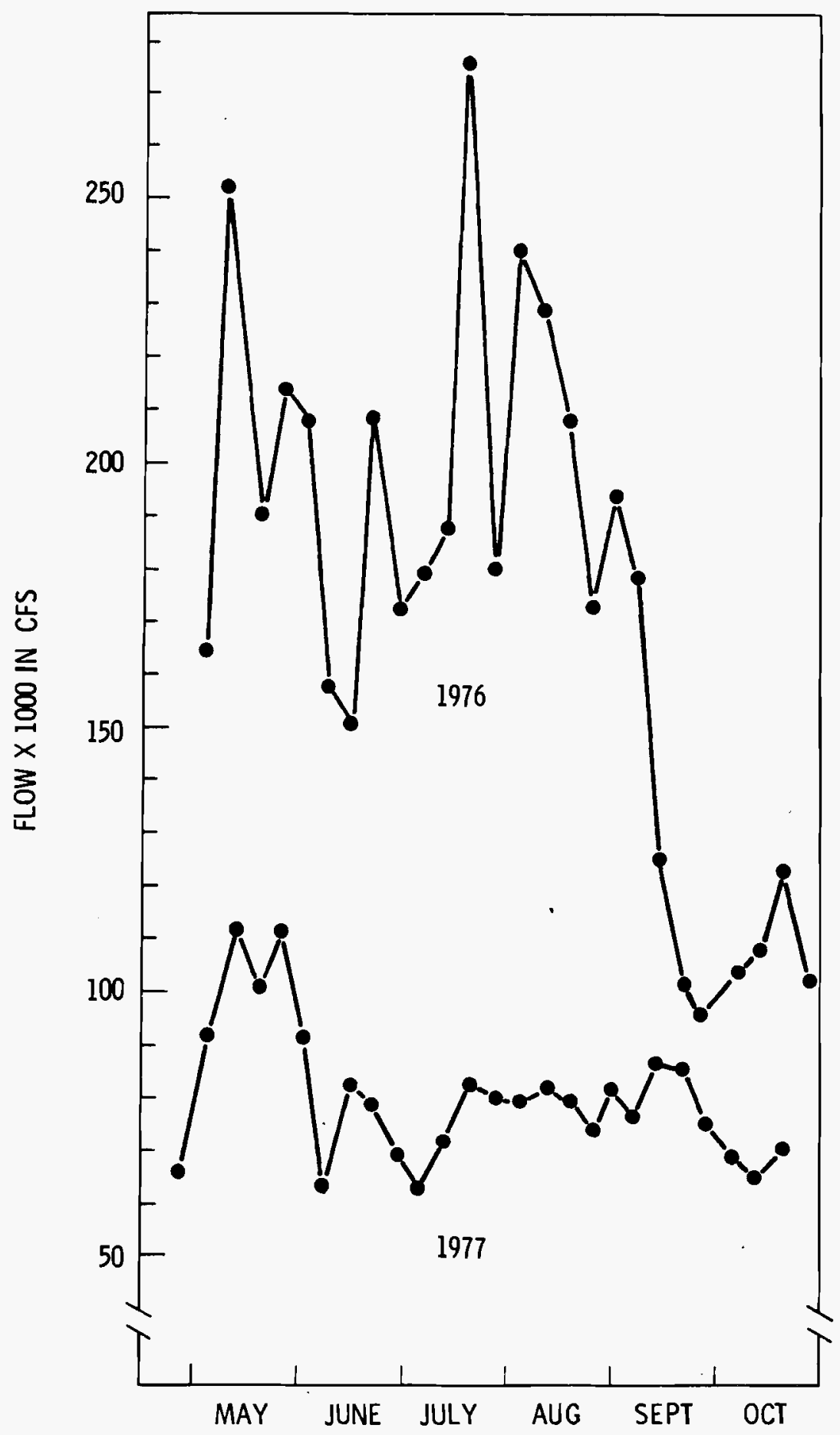

FIGURE 6. Average Week ly Columbia River Flows (Spi11 Plus Discharge) at Priest Rapids Dam from May Through October, 1976 and 1977. (Compiled from unpublished data of the U.S. Army Corps of Engineers). See Figure 8 for interweek ly flow variations. To convert cfs to $\mathrm{m}^{3} / \mathrm{sec}$, multiply by 0.0283 . 


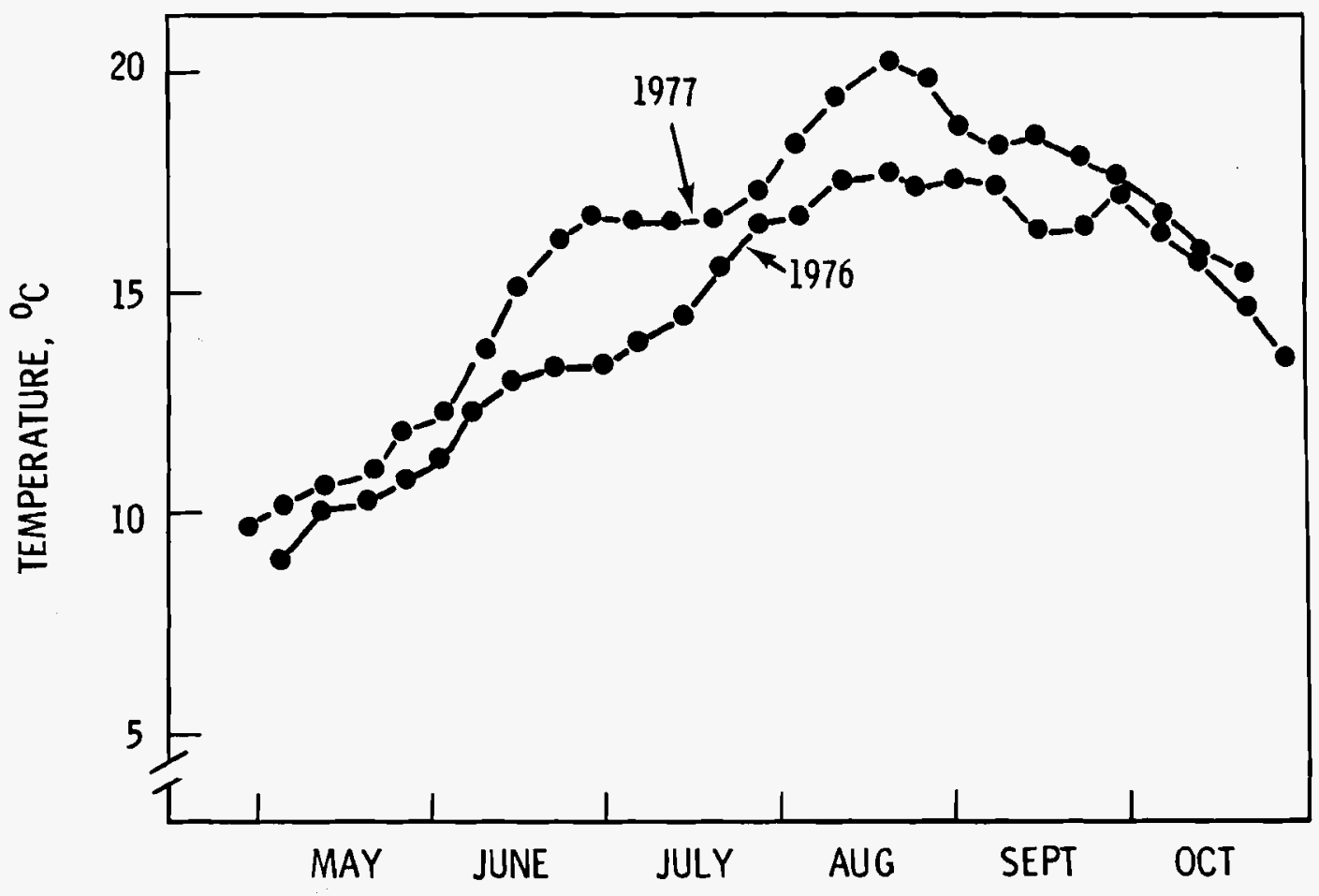

FIGURE 7. Average Week ly Columbia River Temperatures at Priest Rapids Dam from May Through October, 1976 and 1977. (Compiled from unpublished data of the U.S. Army Corps of Engineers). Water temperatures are warmer during summer in low-flow years in the Hanford Reach because solar radiation is more effective.

An entrapment area also occurred on the west side of Hanford Slough that was connected by a series of channels at high water stages. This area contained about 45 pools and 300 puddles with various types of substrates (Figure 9). Those with permeable mud or sand substrate drained in 0.5 to $48 \mathrm{hr}$ by subsurface drainage. Larger pools with less permeable cobble and mud substrate required at least three weeks to dewater from slow drainage and evaporation. On September 15, 400 to 600 northern squawfish fry, 5 yearling black crappie, and 14 adult carp were observed isolated from the main slough in the area. Dewatering was complete by October 15.

Smaller pools commonly contain quantities of aquatic insects. Damselfly and dragonfly nymphs (Odonata) and water beetles (Coloptera, Dyt iscidae) were large forms easily seen under dewatering conditions (e.g. mud or cobblestone substrate and warm temperatures) in field situations. 


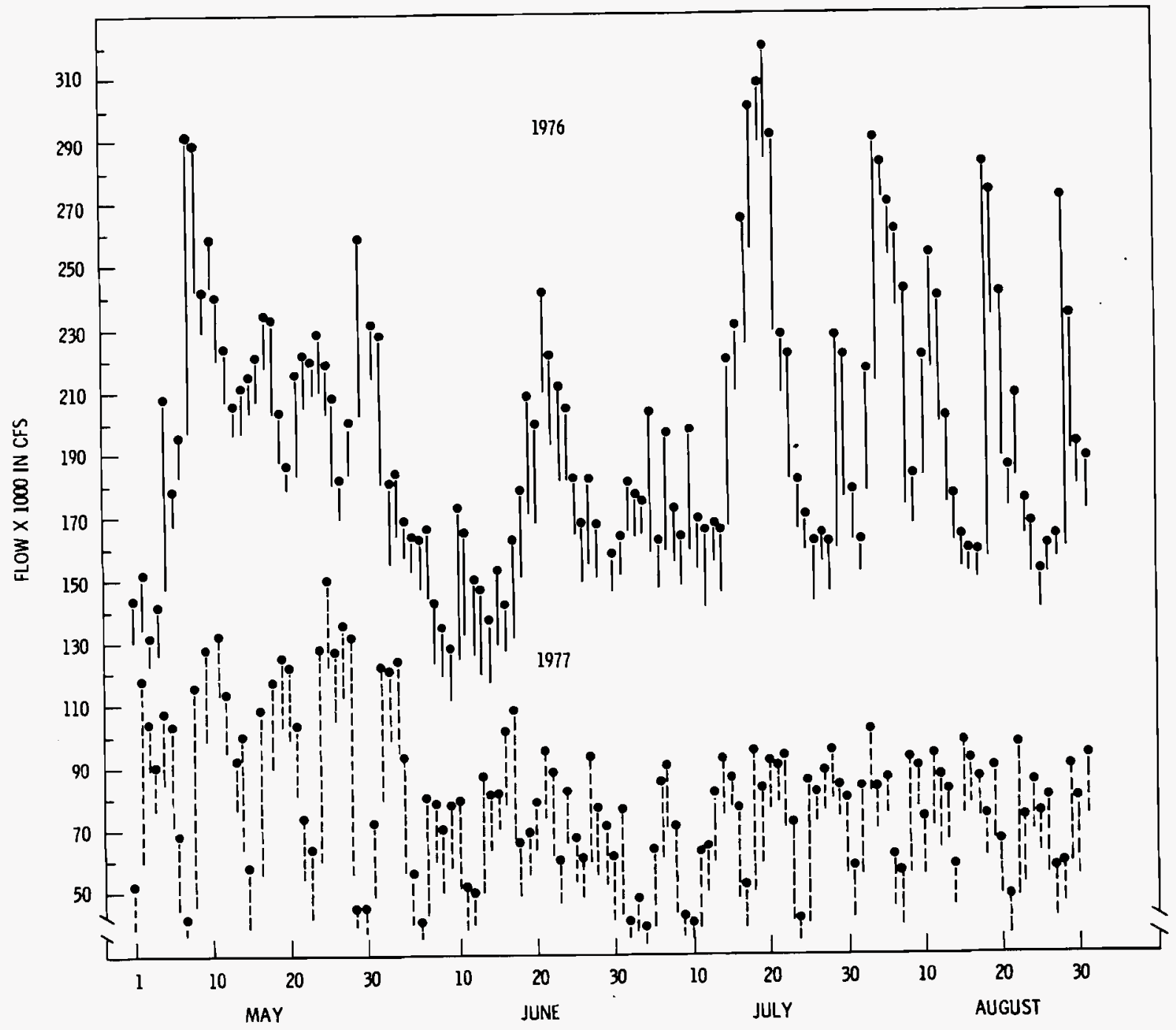

FIGURE 8. Daity Columbia River Flow Patterns (Spill Plus Turbine Discharge) at Priest Rapids Dam from May Through August 1976 and 1977. (Compiled from unpublished data of the U.S. Army Corps of Engineers). Daily and week ly flow variations result from power peaking in response to consumer demand. To convert cfs to $\mathrm{m}^{3} / \mathrm{sec}$, multiply by 0.0283 .

\section{F-Area Slough (North End)}

Six surveys were made in F-Area Slough between July 12 and August 5. Each survey concentrated on one section of the slough, either the north or south end, to provide adequate observation of dewatered areas. 
High water flooded the peninsula at the upper end of F-Area Slough (Figure 10) in mid-summer 1976, forming a channel about $2.6 \mathrm{~km}$ long connecting the river and slough. Ponds formed and drained in the channel periodically as water levels fluctuated in July and August. The ponds would receive an influx of freshwater every 3 or 4 days. As river flows declined in mid-August, passage of water through the channel ceased and seven larger ponds remained. These ponds warmed and drained completely by September 16 .

The north end of the slough contained many small pools and large ponds as the water receded in August 1976,. These ponds ranged from less than $1 \mathrm{~m}^{2}$ ( $2 \mathrm{~cm}$ deep) to $30 \mathrm{~m}^{2}$ ( 1 to $2 \mathrm{~m}$ deep). Dewatering time varied with the amount of groundwater and type of substrate. Small pools with sandy substrate dewatered within $1 \mathrm{hr}$, whereas others took several months to dry.

One pool left by receding water was about $5 \mathrm{~cm}$ deep and contained about 150 largescale sucker, carp, redside shiner and peamouth fry. The fish apparently died from thermal and oxygen stress as the shallow water was heated by exposure to the sun. Another pool measuring 0.5 by $0.3 \mathrm{~m}$ contained 100 dead redside shiner fry. Two larger ponds contained about 800 fish including 150 largemouth bass, 175 smal1mouth bass, 175 carp, 130 pumpk inseed, 125 bluegi11, 36 black bullhead, and four prickly sculpin. This pond did not dry completely until 1977 (see 1977 results).

Another pond about 100 by $800 \mathrm{~m}$ and $2 \mathrm{~m}$ deep contained about 35 adult, 75 yearling, and 3 fry smallmouth bass. In addition, it contained adult and juvenile squawfish, carp, peamouth, redside shiner, and largescale sucker. Only two puddles remained on September 15; they contained about 2,500 dead and dying 0-age fry (a mix of the above species). The puddles dried the next day. Seagulls, starlings and blackbirds scavenged the area. Since no adult fish were found, they were presumably removed earlier by scavengers such as coyotes (Springer 1977). A conservative estimate of loss in this pond was 10,000 adult and juvenile fish.

Several thousand small fish representing the above species and three yearling largemouth bass were found when six other ponds in the vicinity dried earlier. Nymphs and larvae of aquatic insects, primarily dragonflies, damse1flies, mayflies, caddisflies, water boatmen, and nonbiting midge larvae, were commonly found desiccated in various pond basins. 


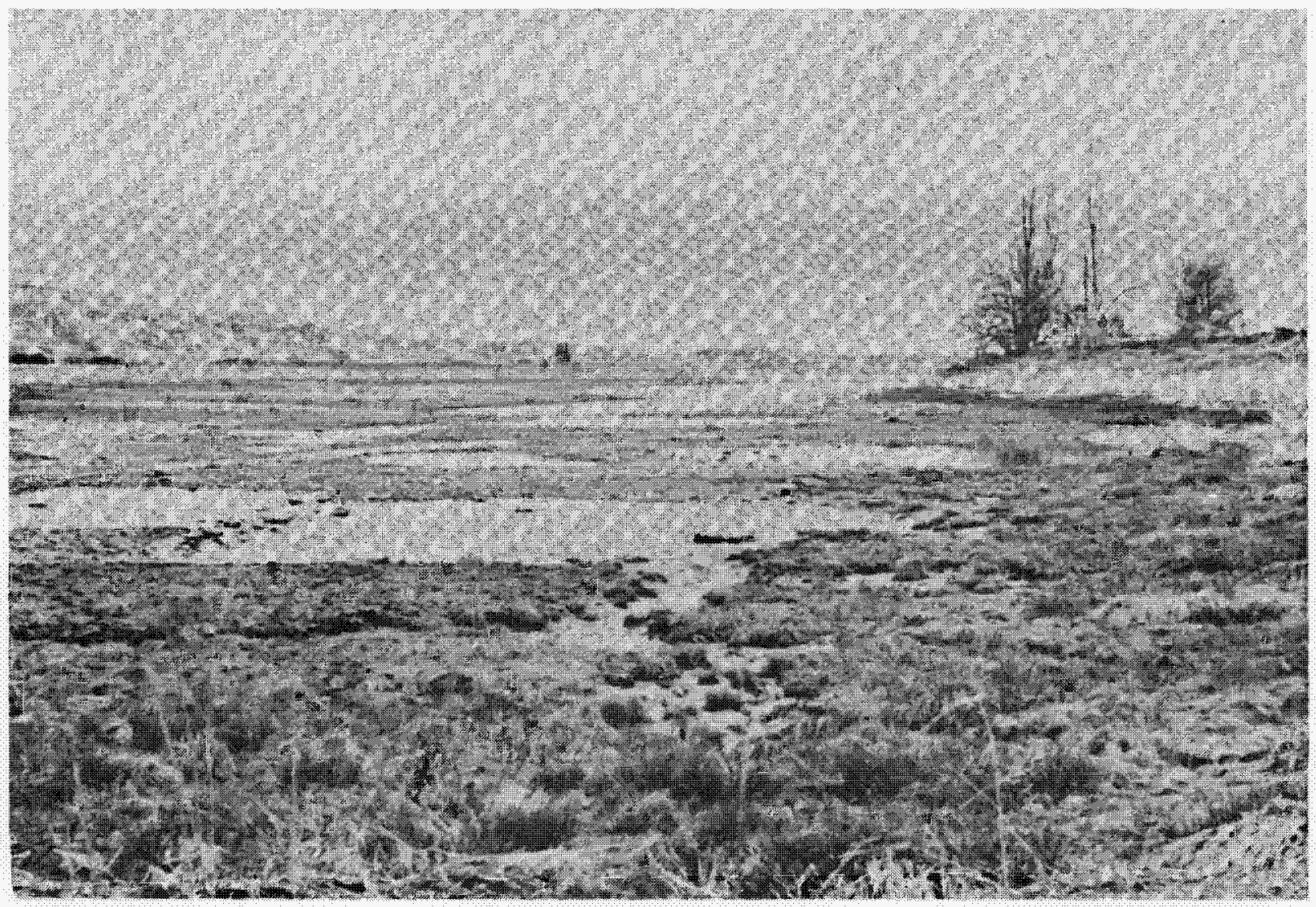

FIGURE 9. The North End of Hanford Slough Facing South During A Low Water Stage. High water inundated the area $24 \mathrm{hr}$ previously. Each pond and puddle represents an effective entrapment area for fish. Repeated flooding and dewatering multiplies entrapment impact. 


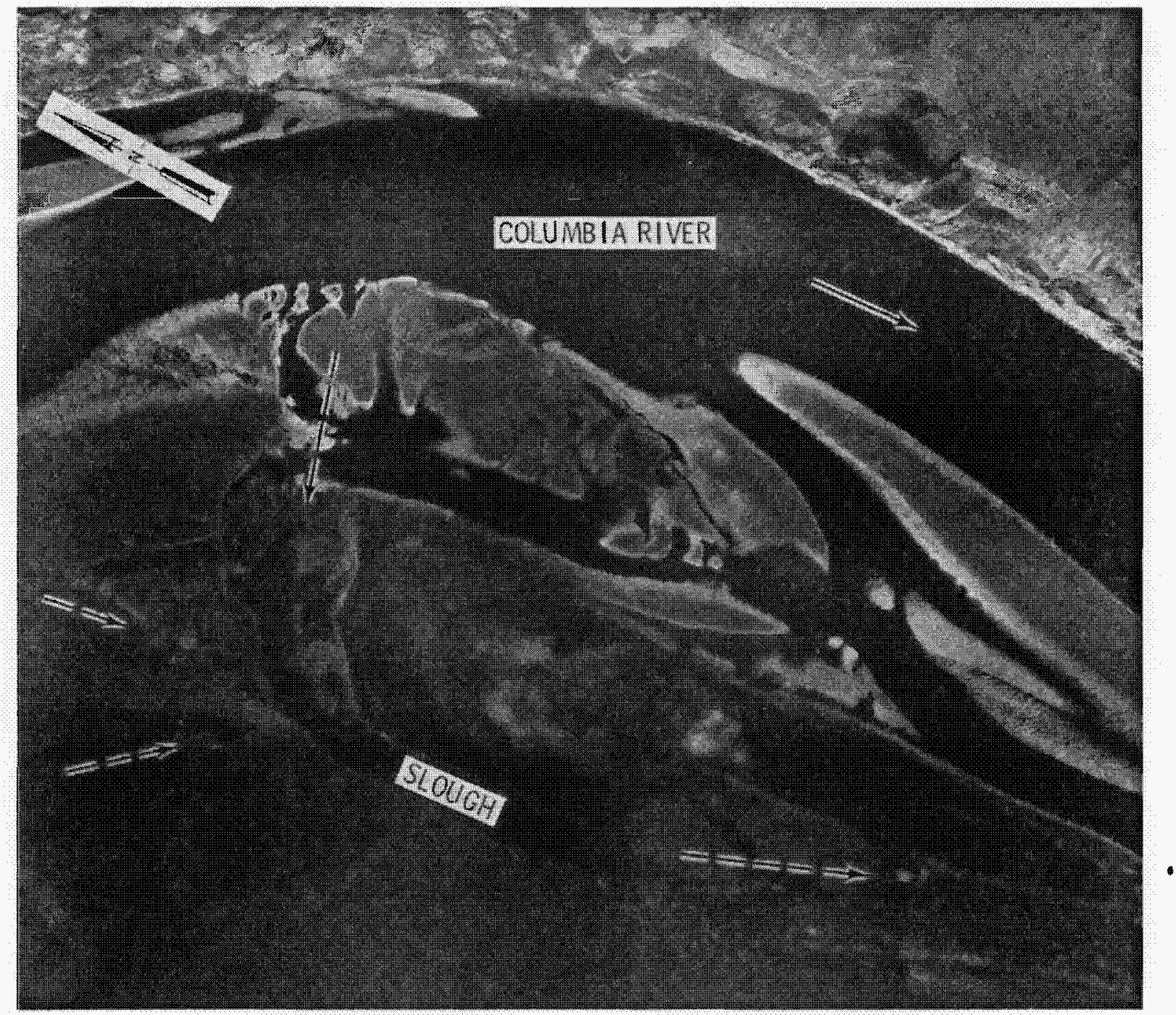

FIGURE 10. F-Area Slough and Environs During a Summer Period of Low Flow. Columbia River Water enters the north end of the slough during high stages (dashed arrows), usually the annual spring spate, and leaves by the south end. The main slough is enclosed during low water stages. Terrain features at the north and northeast ends create numerous areas that entrap fish as high water levels drop. 


\section{F-Area Slough (South End)}

The south end of F-Area Slough was bisected by a bank that retained water in the main slough. The bank extended into a large, shallow area covering about 400 by $200 \mathrm{~m}$. Largescale sucker and squawfish fry, and 0 -age smallmouth bass utilized shoreline cover in this area when it flooded in late August 1976. During intermittent high flows, water entered through two lower portions of the bank and created 125 to 150 pools of various size. Fry entered and dispersed in flooded, grassy areas behind the bank. Receding water then isolated the pools, which usually dried in $24 \mathrm{hr}$. An estimated 200 smallmouth bass, 800 northern squawfish and 1,000 largescale sucker fry were lost in one such occurrence.

\section{White Bluffs Slough}

Chinook salmon fry commence seaward migration during Apri1 and May, and were present during most of the summer high-flow period. Corresponding with the migration, temporary pools that formed at the head of White Bluffs Slough contained juvenile salmonids. In one area, nine ponds contained 50 to 100 chinook fry each. Although all ponds eventually dewatered, some fish may have escaped because the ponds periodicaliy filled and drained as water levels changed. Scrutiny of incompletely dried pools on later dates revealed some dead salmon fry, which apparently succumbed to high thermal and low dissolved oxygen stress. No dead salmon fry were found in completely dewatered pools, but signs of terrestrial predators and scavengers were abundant. Coyotes were seen preying on entrapped adult carp, and tracks indicated similar predation on at least three carp and four largescale sucker carcasses.

Because temperatures in the various Hanford sloughs are often warmer than the river, they are selected by smallmouth bass for spawning, primarily when temperatures in early spring reach $12.8^{\circ}$ to $15.6^{\circ} \mathrm{C}$ (Henderson and Foster 1956). Data from other areas indicate that smallmouth bass generally move to spawning areas at rising temperatures extending from $4.4^{\circ}$ to $15.6^{\circ} \mathrm{C}$; while spawning begins at $14.4^{\circ}$ to $21.1^{\circ} \mathrm{C}$, a drop to lower temperatures will cause spawning to cease (Emig 1966). 
Five nests constructed by smalimouth bass were located at White Bluffs Slough and observed through egg incubation until the fry dispersed. Eggs hatched in only two of the five nests, each of which produced less than 50 fry. A smalimouth bass nest normaliy produces about 2,000 fry (Scott and Crossman 1973), but egg deposition may reach 8 to 9 thousand (Carlander 1977), depending on geographical region and type of habitat. Temperature declines associated with water level fluctuations may impact bass spawning and egg survival.

Male smalimouth bass guarded nests in the slough until mid-Juiy, and gravid females were collected until mid-August. No nesting was detected after the end of July when spawning areas were exposed to high river flows entering the upper end of White Bluffs Slough (Figure 6).

Seven adult bass carrying radiotags remained in the slough until late August, but then returned to the mainstem Columbia River. Departure corresponded with the decline from high to low flow (Figure 6).

\section{Results}

Because of limited water supplies in upstream watersheds and storage reservoirs, overall Columbia River flow through the Hanford area was reduced (Figure 6). There was little excess spill at Priest Rapids Dam to dampen flow variations resulting from power generation. Consequently, response to peak power demands resulted in considerable daily and weekly variation in flow regimes (Figure 8 ). Greatly reduced flows occurred on weekends when industrial electrical consumption was reduced, and vast stretches of shoreline zone were periodically exposed to dehydration.

\section{Hanford Slough}

Chinook salmon fry were first detected in Hanford Slough on March 22. Changes in Columbia River water levels from flow regulation intensified toward the end of March as water shortages were predicted for the pending summer. Three stranded salmonid fry were found in one small pond ( 3 by $2 \mathrm{~m}$ ) and two were found in another pond ( 3 by $3 \mathrm{~m}$ ). Birds were actively foraging in the area. Hence, most dead fish probably were removed before survey. 
The large pond at the northern end of Hanford Slough (Figure 4A), which was isolated during falling water levels in mid-September 1976, contained the following surviving fish: adult largemouth and smallmouth bass, crappie, bluegill, pumpkinseed, three species of bullhead, and adult carp. Weight-length condition factors indicated that the adult bass were at normal weights after overwintering ( 7.5 mo entrapment), but smaller bass $(25.6$ to $30.7 \mathrm{~cm}$ total length) were more robust than the larger ones. Forage species utilized by bass were either large or absent, presumably because feeding bass removed smaller individuals selectively.

Sampling in November 1977 indicated that the abundance of fish in the pond was reduced, and that forage fish suitable for predator fish consumption were absent. Bass condition factors indicated chronic malnutrition. Intensive sampling in February 1978 produced only 11 emaciated carp, which apparently survived because of their ability to utilize algae and substrate detritus as food.

F-Area Slough

High water from the Columbia River flooded F-Area Slough through its northeastern end for 2 to 6 days in early April and permitted fish to enter. The receding water trapped all fish in the slough until early March, 1978. The enclosed water body was sufficiently large and deep that it remained suitable fish habitat through the summer and fall.

Some chinook salmon fry entered F-Area Slough during the high-water period in April. These fish could not complete their spring seaward migration and were exposed to predator fish the rest of the year.

Falling water levels after the April flow eventually isolated several areas that contained fish (Figures 11,12 ). Two dead chinook salmon fry were found in a small dehydrated pool $\left(0.5 \mathrm{~m}^{2}\right)$ situated in a channel between the river and the slough. A pond measuring 7 by 3 meters $(0.35 \mathrm{~m}$ deep) in another channel contained about 80 yearling smallmouth and largemouth bass, 30 adult bluegill, and 8 adult carp. These fish survived the summer but were lost during winter to terrestrial predators and freezing. 

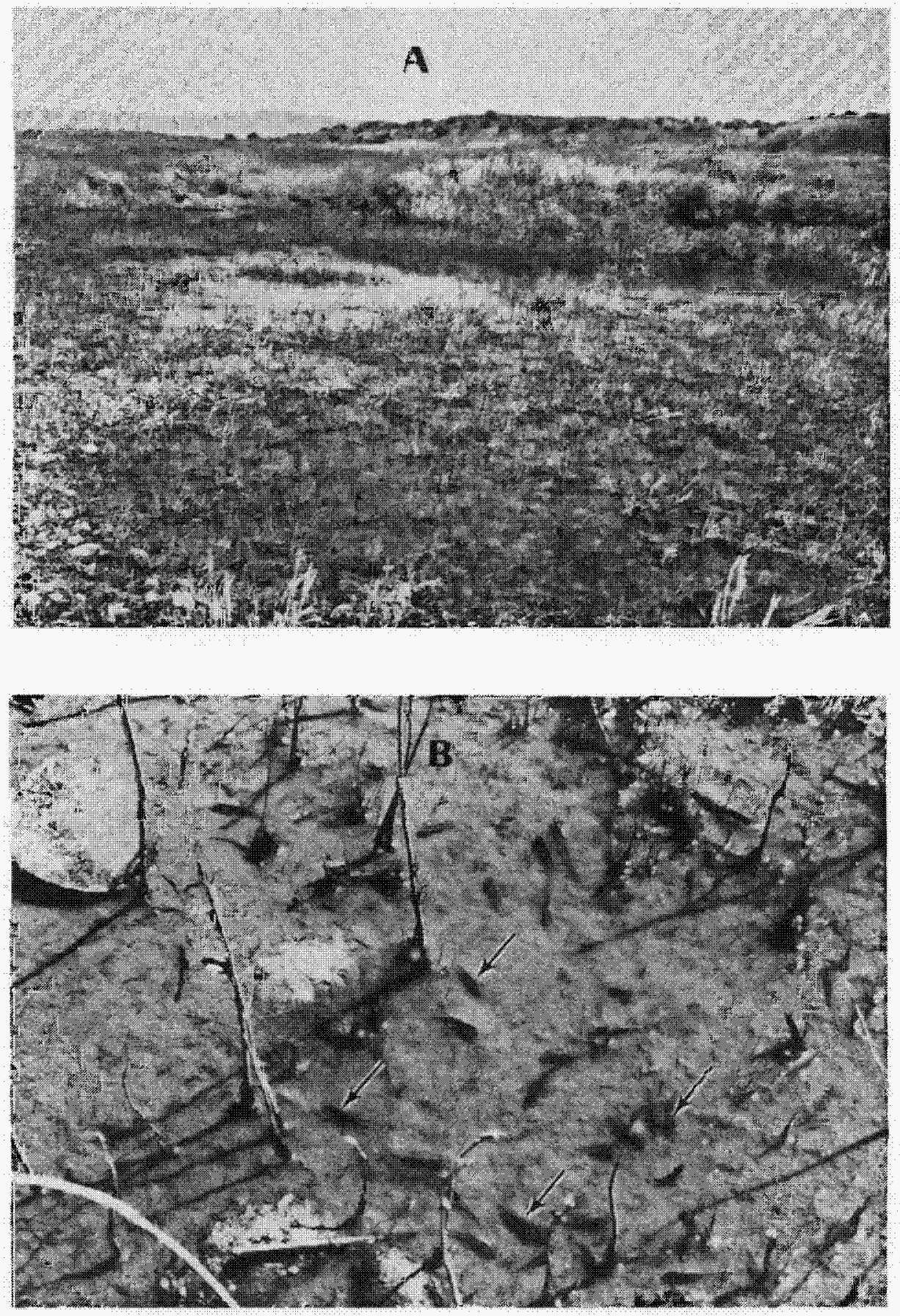

FIGURE 11. A Flooded Grassy Area at the Head of F-Area Slough After the Apr il 1977 Spate (A). Numerous chinook salmon fry were isolated as water levels fell (B) and eventually perished as the area dewatered. Grassy areas were particularly attractive to fish fry because they provided cover as well as food. 

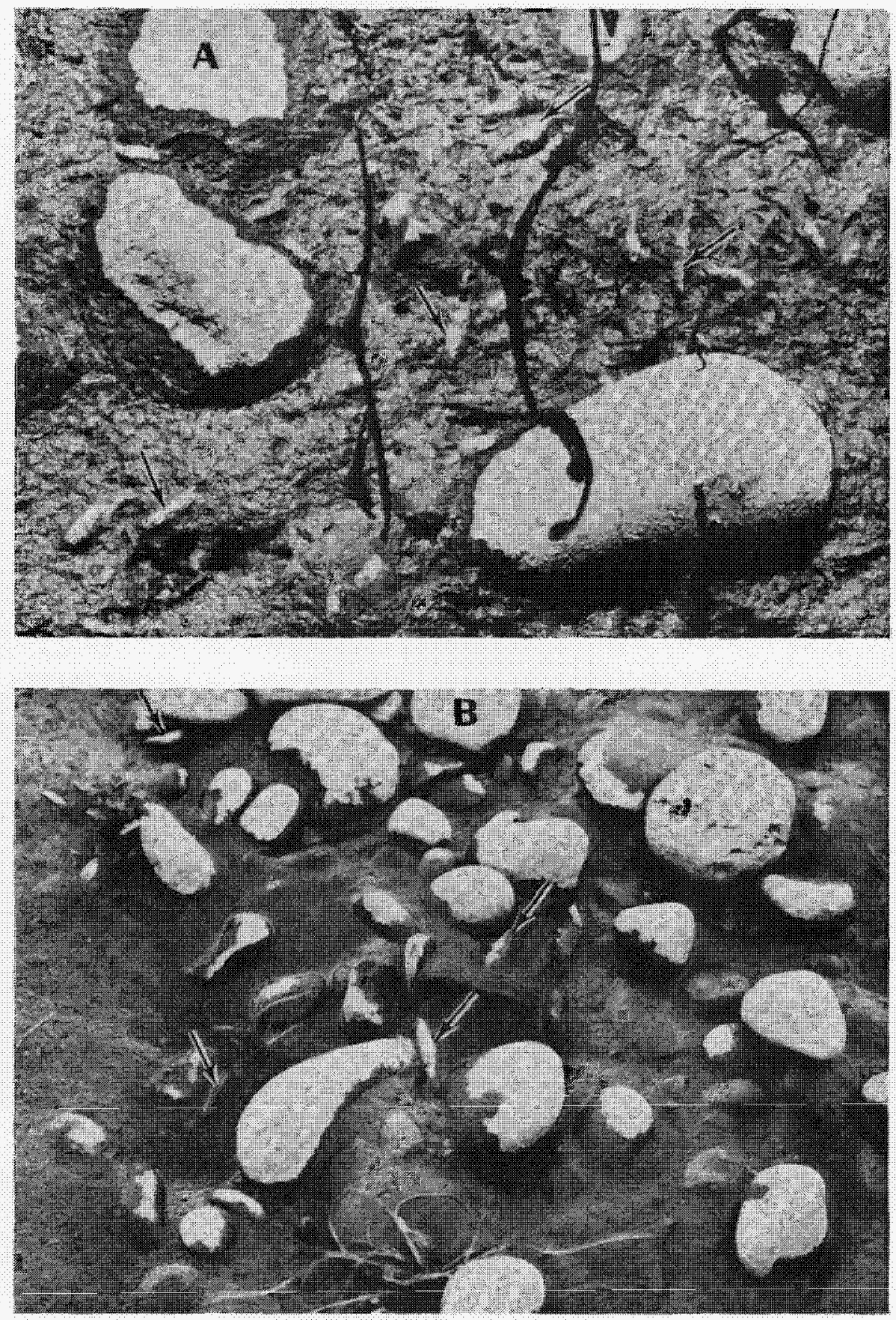

FIGURE 12. Chinook Salmon Fry (arrows) in Mud and Cobblestone Bottom of Dewatered Ponds. Fish were covered with mud in their final struggles (A) or worked their way to gravel interstiches (B), while others were removed by predators or scavengers. Enumeration of stranded fry provides only conservative estimates of actual losses. 


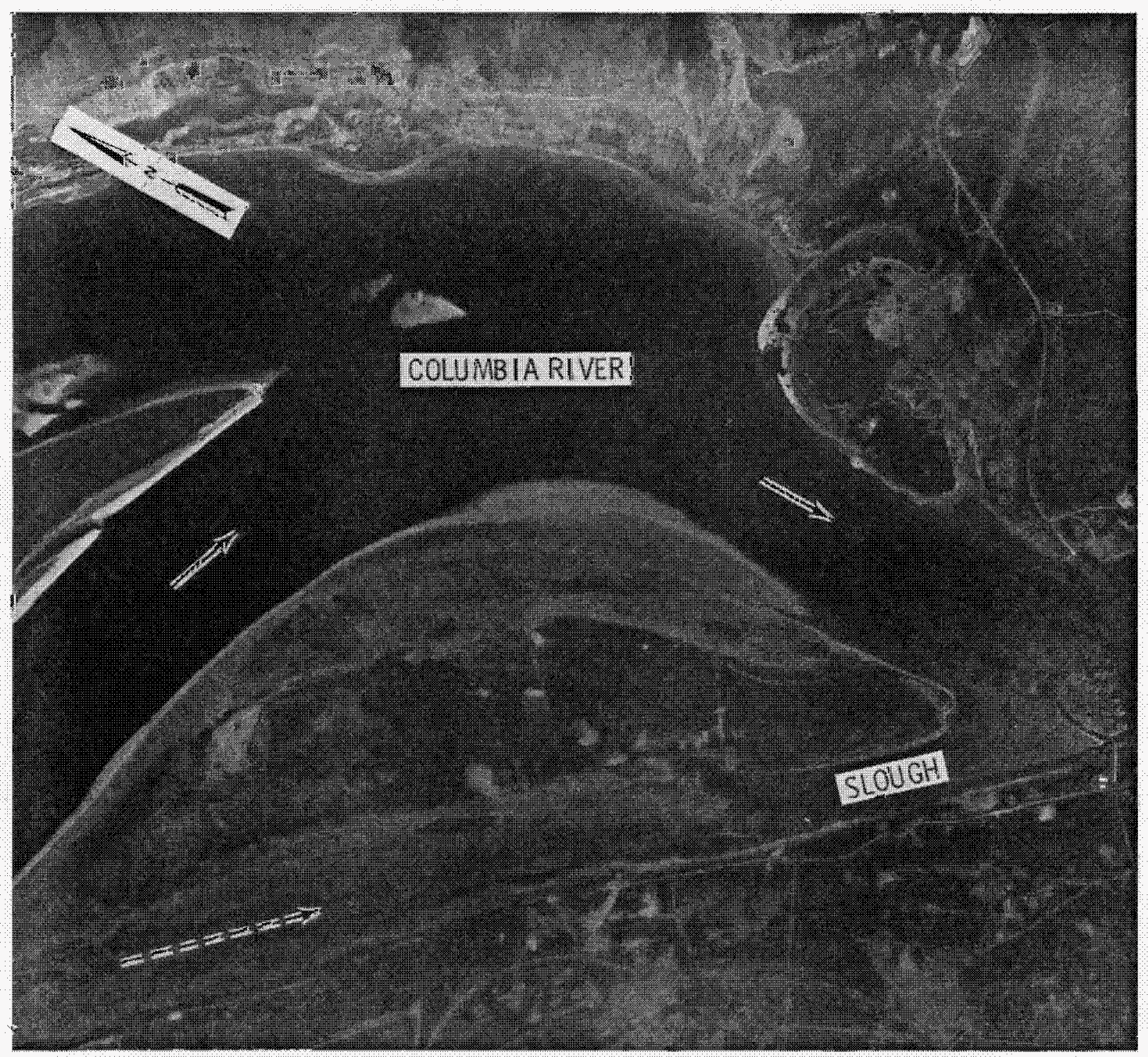

FIGURE 13. White Bluffs Slough and Environs During a Summer Period of Low Flow. The Columbia River enters the northwest end of the slough during high stages (dashed arrow). The main slough is open at the lower end even during low-water stages. Hence, water level rises and falls daily in response to upstream discharges. Ponds form at the head of the slough, and smallmouth bass spawn in the narrow channel. 
A small but deep circular pond ( $3 \mathrm{~m}$ diameter, $2 \mathrm{~m}$ deep) was isolated west of the main F-Area Slough in September 1976. Sampling at that time indicated that 100 smallmouth and largemouth bass, 100 pumpkinseed, 50 bluegi11, 35 black bulthead and several carp were confined in the pond. Sampling in late May, 1977, revealed no bass, but7head, or carp. The pond had decreased to about one-fourth of its original size with a maximum depth less than $0.5 \mathrm{~m}$. However, the bluegill and pumpkinseed had apparently spawned, increasing the ir number to about 1,000 small fish. The pond drained completely by late July 1977.

\section{White Bluffs Slough}

The slough (Figure 13) remained generally at low water stages throughout the summer due to low Columbia River flows in 1977 (Figure 6). Adult fish were trapped almost daily in the narrow channel leading from the northwestern end as water levels fluctuated in response to daily power demand. However, periodic inundation allowed the adult fish to enter or leave. Adult fish generally inhabit deeper pools, particularly as water levels drop, and avoid shallow areas that drain and dehydrate rapidiy.

One isolated pool ( $3 \mathrm{~m}$ diameter and $0.5 \mathrm{~m}$ deep) at the north end of White Bluffs Slough was sampled by electroshocker in mid-May. One adult smalimouth bass (gravid female), 130 chinook salmon fry, 5 adult carp, 2 threespine stick leback, 1 redside shiner and 1 squawfish fry were recovered. About 80 to 100 chinook salmon fry escaped capture but were seen. The adult smallmouth was released in the slough and the other fish were returned to the pool, which then dried in $24 \mathrm{hr}$. Scrutiny the next day revealed on $7 y \quad 8$ dehydrated chinook salmon fry under cobbles. Tracks indicated scavenging by a coyote, a racoon, seagul1s, and blackbirds. Further examination revealed that 2 crayfish, 4 leeches, and about 400 dragonfly nymphs, caddisfly larvae and snails were dead beneath substrate cobbles.

Another pond further north contained an estimated 2,000 chinook salmon fry and 5 adult carp. The fate of these fish was not determined. However, pond temperature was $20.5^{\circ} \mathrm{C}$ and approaching the $25^{\circ} \mathrm{C}$ lethal limit (Brett 1952) for juvenile salmon. 
$\underline{\text { Remarks }}$

Observations on the effects of water level fluctuations in the Hanford Reach extend observations made during the Low-Flow Experiment in regard to entrapment of fish. However, the effects noted were more characteristic of present-day flow regulation at Priest Rapids Dam during high-water (1976) and low-water (1977) years. Under present hydroelectric operations, daily water level fluctuations during high-water years may be more extreme than during low-water years (Figure 8).

Priest Rapids Dam was operationa 1, and the first flow records were available, in 1960. Most water during the annual spring spate in 1960 was passed over the dam with little day-to-day fluctuation, and the spate lasted until late July (Figure 14). In 1970, ten years later, a reduction was evident in the annual spate due to filling of upstream reservoirs.

The Columbia River has historically experienced variable high spring flows that subsequently recede to relatively stable flows of late summer and fal1. Endemic species of river fish evolved in harmony with this cycle. Juvenile fall chinook salmon, originating from eggs deposited by adults in October and November, move seaward during the annual spate. Largemouth and smallmouth bass, both introduced species, survive in the mid-Columbia River by spawning in warmed inshore areas and sloughs during Apri1, May, and June. Although the spring spate impacts smallmouth bass spawning activity and influences reproductive success each year, populations of adult smallmouth bass remain sufficiently large to support a local sport fishery.

The Columbia River's spring spate is a natural phenomenon, whereas water level changes imposed by power generation are not. Historical water level changes imposed by a spate cover a wide range, upward and downward, over a period of a few months. Water level changes from power generation result in more abrupt and frequent changes, but these are usually of a lesser overa 11 magnitude than occur in an unregulated spate. Man-induced fluctuations from power generation will prevail most of the year as long as water resources in upriver reservoirs are insufficient to meet all competing demands. 


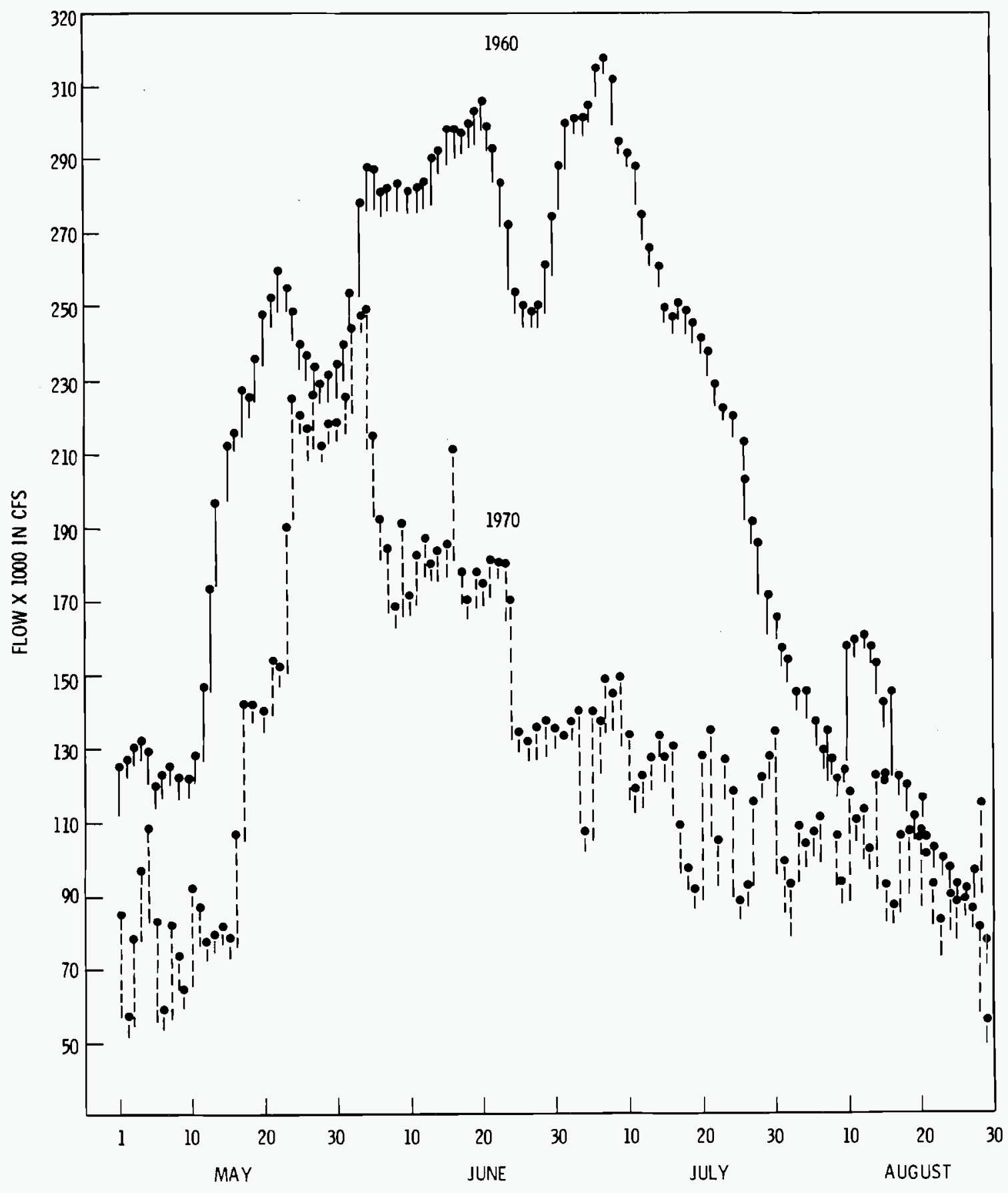

FIGURE 14. Daily Columbia River Flow Patterns at Priest Rapids Dam During the Spring and Summer of 1960 and 1970. Priest Rapids was completed in 1959 and the first flows over the dam occurred in 1960. Compare, with Figure 8 for recent flow regimes. To convert cfs to $\mathrm{m}^{3} / \mathrm{sec}$, multiply by 0.0283 . 
The effects of water level fluctuations in shoreline zones depends not only upon the vertical range of the fluctuation but upon shoreline topography. Generally, the more irregular and gentle the slope and the more depressions it contains, the greater is its potential for entrapment of fish species. Most of the river margin in the Hanford Reach of the Columbia River is limited in vegetation and is composed of gravel and cobblestone with an underlying layer of packed sand or silt. The vegetative zone lies above the water level fluctuations of the main reach most of the year, but may become flooded during periods of maximum runoff (e.g., the spring spate). Pools and sloughs existing in shoreline areas vary in entrapment potential depending upon their size, elevation, depth, substrate, vegetative cover, and other features.

Less area is exposed to water level changes on steep slopes than on gradual slopes (Figure 15A). Thus, a steep shoreline zone has less potential for entrapment of fish. Furthermore, a gradual slope usually contains more shallow depressions that create temporary pools for entrapment of fish fry. Larger depressions in the area covered by fluctuating water levels (fluctuation zone) are periodically filled when water levels rise and become pools as water levels recede. Pools with permeable bottom substrates remaining above the minimum prevailing water level drain relatively rapidly (Pool A, Figure 15B). However, they may not drain completely between each successive withdrawal because of variations in extent and duration of low flows. Pools with impermeable bottom substrates or those reaching below the fluctuation zone (Pool B, Figure 15C) normally remain filled during extended periods of low flows. River water enters during peak flow periods and fish move in and out. Such pools become semi-permanent and may persist for months during extended low-flow periods.

The typical slough is open at one location and river water enters during high-flow periods. Some small, shallow sloughs fill and drain with each rise and fall of the river's water level (Figure 16A). Larger and deeper sloughs retain water and become temporarily isolated pools as water levels recede (Figure 16B). Such isolation may persist for months during extended periods of low flows. River water may enter at the head of a slough during peak flow periods, and a series of connected pools remain that retain water as flows decline (Figure 16C). When river level fluctuations become cyclic on a daily 

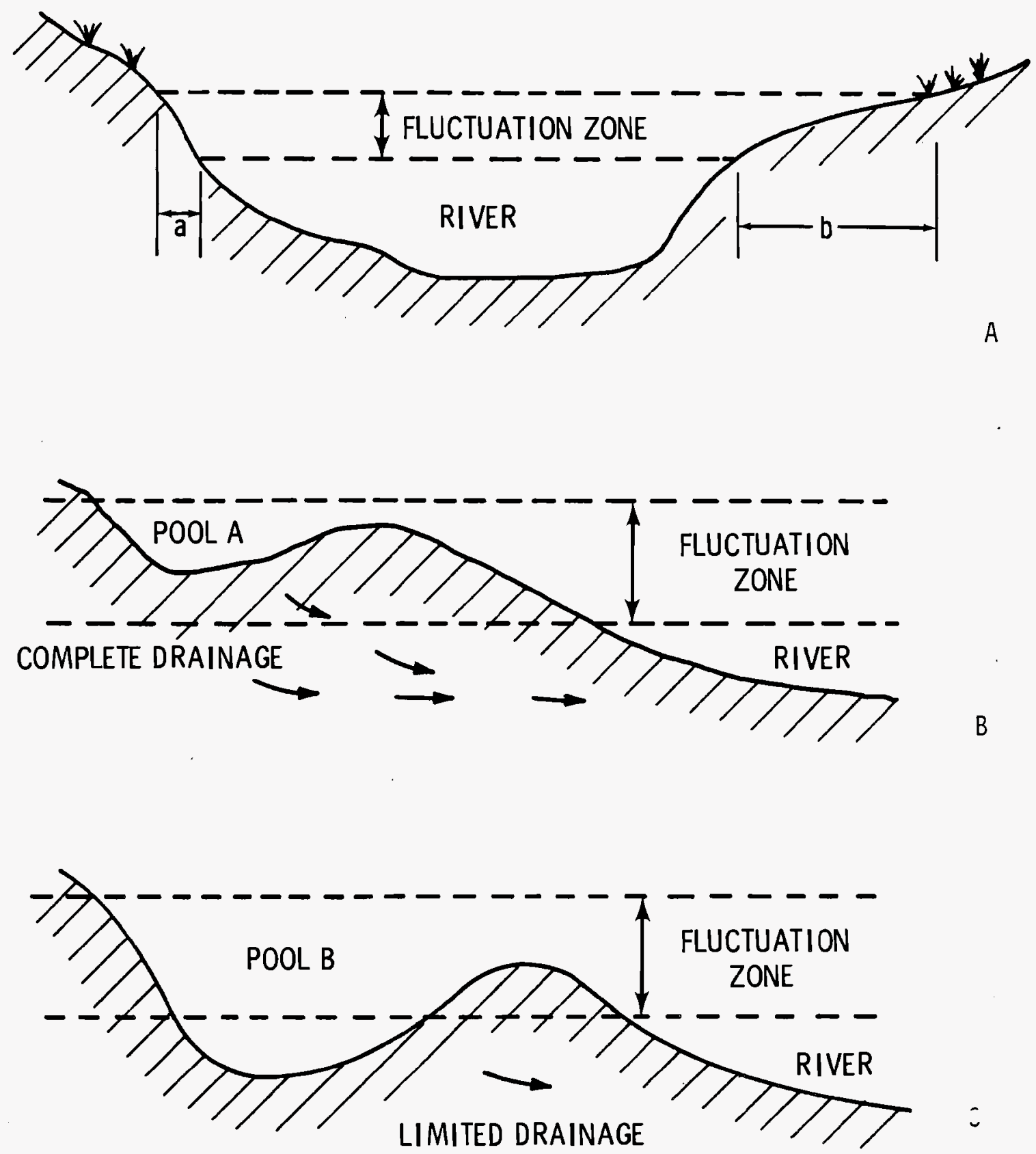

FIGURE 15. Typical Situations Existing in Pools Subject to Filling During River Level Fluctuations in the Hanford Reach 

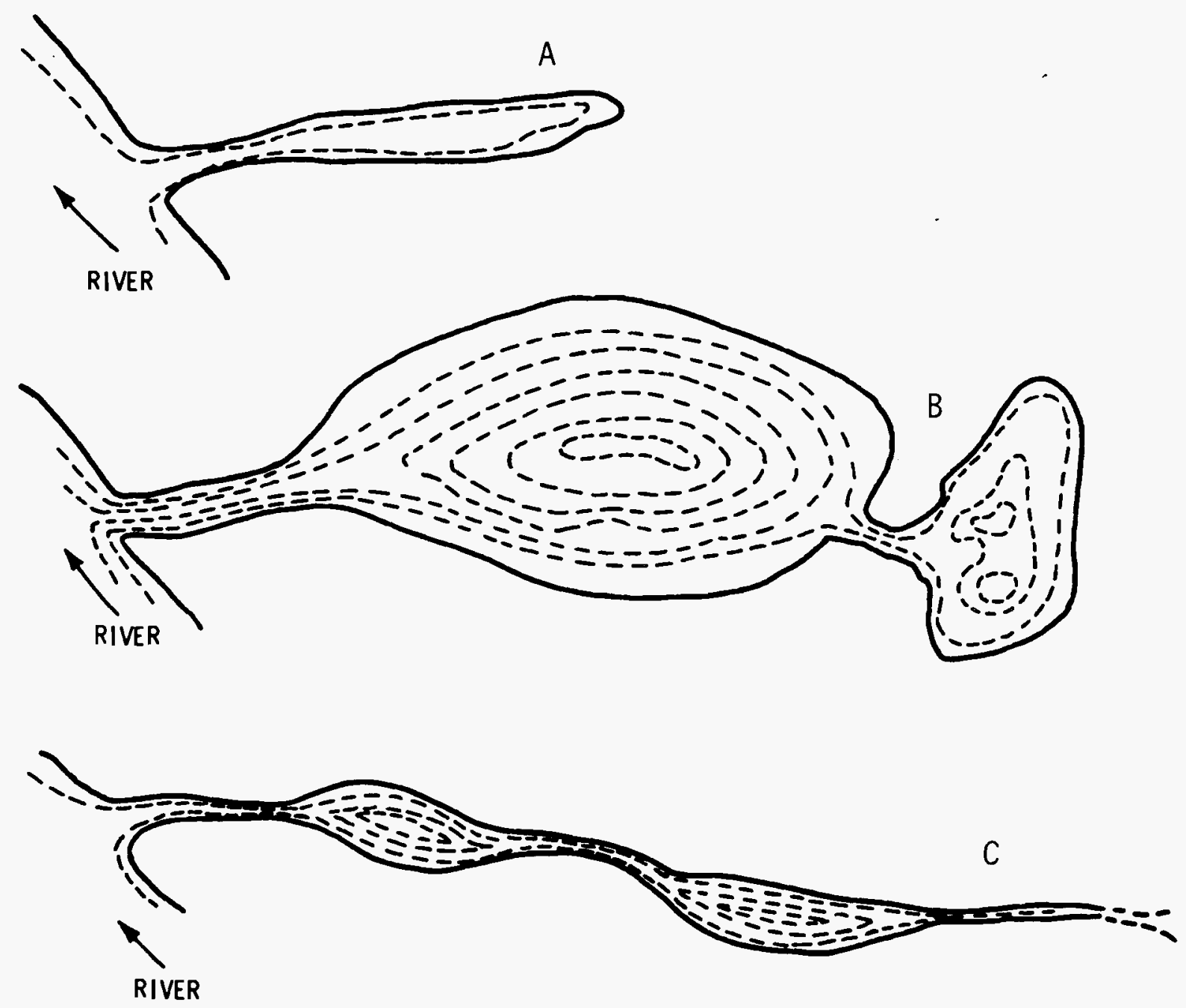

FIGURE 16. Typical Situations Existing in Sloughs Subject to Filling During River Level Fluctuations in the Hanford Reach

and weekly basis, water may enter only at the "outlet" of a slough, extending inward only as far as the rise permits (Figure 16C). Temperatures in pool and slough areas are subject to abrupt changes whenever river water enters.

Conclusions based on 1976 and 1977 field observations are:

1) Water level fluctuations from power generation should be minimized from late March through June, because this period corresponds to: 1) the emergence of juvenile fall chinook salmon that often feed in shoreline zones prior to or during seaward emigration, and 2) the spring spawning period of adult smallmouth and largemouth bass. 
2) Many fish larvae affected by receding water are those of the so-called "coarse" species (suckers, sculpins, cyprinids) with limited economic value. These fish exist in abundance, and unoccupied habitats are soon replenished by fish migration (short term) and reproduction (long term).

3) Bird "predation" on stranded fish, in both pools and in completely dewatered areas, often involves scavenging. The Great Blue Heron is, perhaps, the main avian predator. Scavengers include seagulls, redwing blackbirds, species in the "sandpiper" group, killdeers, crows, ravens, starlings, coyotes, and mink.

4) Loss of aquatic invertebrates (aquatic insects, crayfish, oligochaetes, leeches, plankton, copepods) from dewatering of shoreline areas probably effects only a small portion of available populations. Many destroyed organisms are eventually replaced by natural dispersal and reproduction processes from populations existing in deeper water.

5) Invertebrate population densities in shoreline zones periodically exposed and flooded will be lower than those in unaffected areas.

6) Losses of fish from water level fluctuations can be quantified by an extensive monitoring and sampling program. However, such losses may not be reflected at existing adult population levels. Possible exceptions are chinook salmon and smallmouth bass, which are limited in number, seasonally vulnerable to flow changes, and directly harvested (cropped) by man. 


\section{BASS TAGGING STUDIES}

Radio-Tagged Fish

Radio transmitters were placed on seven adult smallmouth bass at White Bluffs Slough in 1976. Fish residence was monitored from mid-March until late August, the annual spring spawning period. Fish remained in or near the slough and were temporarily trapped several times in deep pools as water levels fluctuated. However, water levels remained relatively high until the spawning period passed (Figure 6). All fish survived and returned to the main Columbia River as water levels declined in late August and September 1976. Spawning success of smallmouth bass in White Bluffs Slough was low (see preceding section).

Forty adult smallmouth bass $(37.2 \pm 2.5 \mathrm{~cm}$ standard length) were tagged with radio transmitters at White Bluffs (15 fish), F-Area (15) and Hanford (10) sloughs during 1977. An additional 120 adult bass were marked with dart tags at the three sites. Spawing activities of radiotagged bass began in late Apri1, and egg hatch was complete by mid-June.

Smallmouth bass radiotagged at White Bluffs Slough remained in the area until late June, and were periodically isolated in deep pools during that time. However, 13 of the 15 tagged fish returned to the main Columbia River when spawning was complete in 1977. The other two fish were trapped in pools at the northern end of the slough and remained there until tag-battery failure in September 1977. Contrasting high and low flows in 1976 and 1977 (Figure 6) had little apparent affect on the survival of adult smallmouth bass in White Bluff Slough during the spawning period. Even though water levels varied daily, the adult fish avoided entrapment situations that might lead to direct mortality as they attempted to spawn.

Adult smallmouth bass entered F-Area Slough during April 1977 when high flows connected the slough to the Columbia River for a few days. The fish were probably seeking warm-water areas to spawn. Radio-tagged fish were trapped as the river receded to summer low-flow regime. With no new flow influx, slough volume gradually declined throughout the summer. Three large 
ponds separated by sand and gravel bars eventually formed. Radio-tagged fish remained trapped in these areas until a spate in March 1978. A11 movement was confined to the ponds.

Adult smallmouth bass in Hanford Slough area were radio-tagged March 22 1977. Some bass were trapped periodically in the northern end of the slough as river levels fluctuated. However, these fish escaped and returned to the Columbia River in late June. Smallmouth bass avoided entrapment by moving into deeper water of the Columbia River near the open end of the slough when water levels decreased, and returning to the slough when water levels increased.

After leaving spawning areas in White Bluffs and Hanford sloughs, radio-tagged smallmouth bass remained near the slough outlets for 1 to 2 weeks (Montgomery and Fickeisen 1978). Bass at White Bluffs Slough remained in a pool adjacent to the mouth and favored deeper water at depths of 6 to $16.5 \mathrm{~m}$ (Figure 17B); during observation, mean distance moved downstream was $1.8 \mathrm{~km}$. Bass at Hanford tended to move further downstream (Figure 17A), but movements were largely random. One bass moved $61 \mathrm{~km}$ downstream, but mean distance moved by all bass recovered was $15.1 \mathrm{~km}$ (Montgomery, Fickeisen and Becker 1980). Figure 17 shows typical movements of adult smallmouth bass at White Bluffs (tag 250) and Hanford (tag 750) sloughs. Movement within sloughs open to the river is partially due to changing river flows. Fish move to deeper water near the slough outlets as water levels decline and return to shallower water as water levels increase.

Dart-Tagged Fish

Dart-tagged smallmouth bass trapped in F-Area Slough and recaptured during October 1976 and March 1977 had relatively lower condition factors based on fish weight in relation to length. These data were compared with smallmouth bass taken in another area open to the Columbia River 30 m north of the study site. The diminished supply of forage organisms in F-Area Slough apparentiy restricted bass growth. 


\section{A. HANFORD SLOUGH \\ TAG 750}

\section{B. WHITE BLUFFS \\ TAG 250}

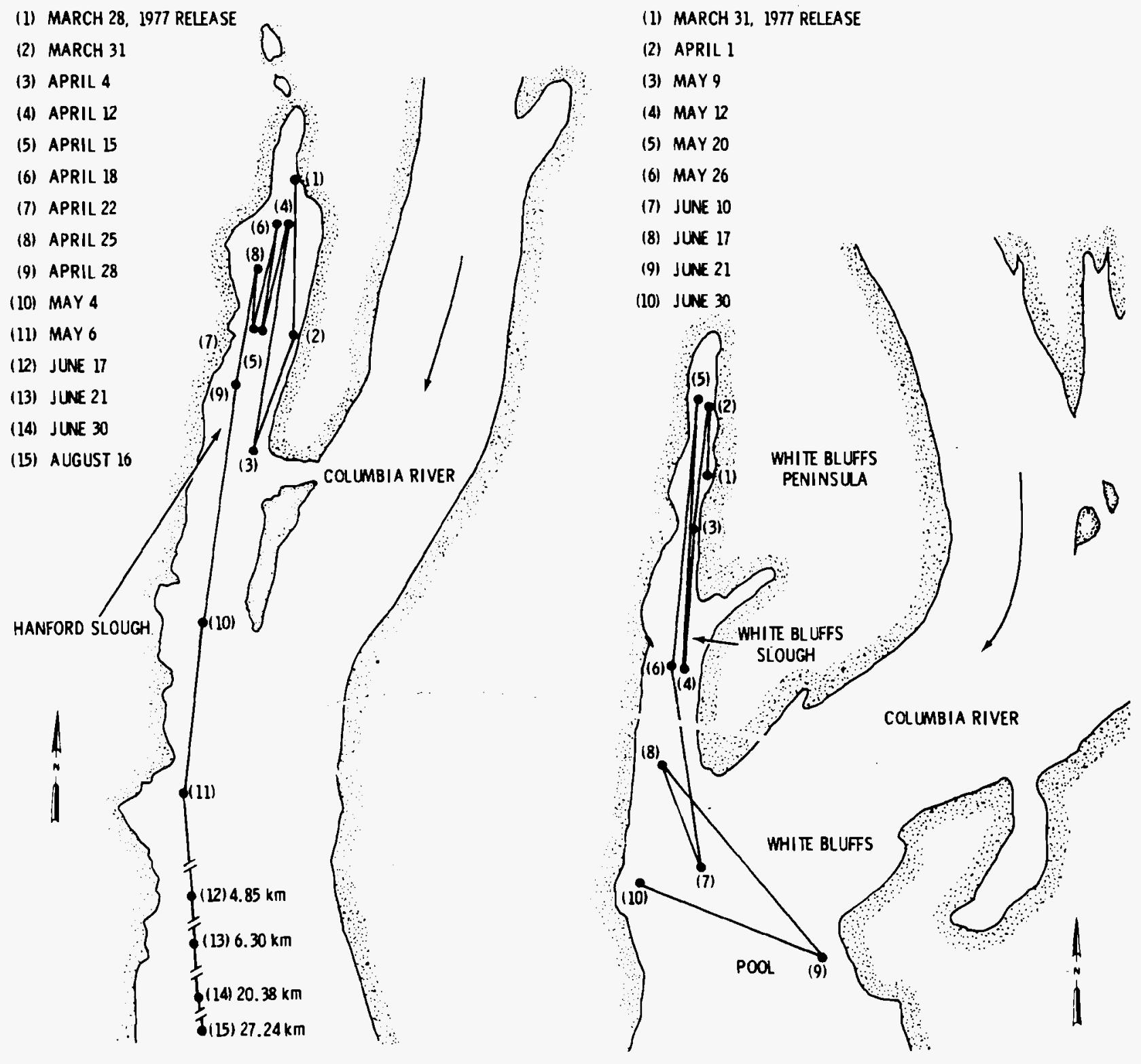

FIGURE 17. Movement of Radio-Tagged Smallmouth Bass at Hanford and White Bluffs Sloughs (from Montgomery and Fickeisen 1978) 
Recaptures of dart-tagged bass after the March 1978 spate revealed that some bass stayed in the F-Area Slough even though high water permitted their departure.

Some smallmouth bass with dart tags moved between study sites. One adult male tagged at Hanford Slough on March 22, 1977, was recaptured May 17, 1978, guarding a nest at F-Area Slough. One adult female tagged at White Bluffs Slough May 12, 1977, was recaptured in gravid condition on June 28, 1978, at Hanford Slough.

Based on reports received from sport fisherman, smallmouth bass with dart tags that subsequently were recovered from the main Columbia River also showed a general downstream movement. One bass tagged on Apri1 28, 1978, at White Bluffs Slough moved $62.5 \mathrm{~km}$ downstream before recapture about two weeks later. Another bass was recovered $63 \mathrm{~km}$ downstream after a longer release period.

$\underline{\text { Remarks }}$

Radio tags provide daily information on fish movement. Dart tags provide information only when labeled fish are recovered and interim movement is unknown. In either case, movement can be affected initially by stress from capture and tagging, and subsequently by the burden of a tag carried by individual fish. Within these limits, data on movement of tagged smallmouth bass provide a basis for evaluating possible effects from seasonal, week ly, and daily changes in river flows at Hanford. It is not always possible to distinguish between natural seasonal movement and movements influenced by $r$ iver level fluctuations. But entrapment of tagged bass can be easily determined.

Tagging indicated that adult smallmouth bass were present at the study sites in late March. Many bass returned to the mainstem Columbia River after the spawning period in August 1976 and late June 1977. Early movement to inshore areas such as sloughs may reflect 1) increased fish activity as river temperatures increase in the spring, and 2) early selection by fish of future spawning areas based on slight but measureable warming of water compared to water passing downstream in the main channel. Warming of inshore areas is greatly influenced by mass water movement that, in turn, is influenced by water level fluctuations. 
Conclusions resulting from smallmouth bass tagging studies at Hanford are:

1) Adult bass may be entrapped for various times by fluctuating water levels during the spring spawning period. Most adult fish survive by entering deeper pools on the river margin that do not dewater or become excessively warmed.

2) Adult bass trapped in larger, deeper pools can survive for several months or more if the water does not drain. Eventually, however, forage organisms (prey) may be reduced so that bass (predators) suffer from malnutrition and may eventually starve.

3) Water level fluctuations can affect bass reproductive success by flooding nests with cooler water, depositing silt, driving away adult bass guarding nests, exposing bass eggs to desiccation, and stranding the recently emerged fry.

4) Movement of adult bass leaving spawning areas in late summer appears to be primarily downstream. This may be an experimental artifact in relation to dart-tagged fish because sport fishing pressure, and hence recovery, is more intense below the study area than above. Yet radiotelemetry showed a similar trend. 


\section{ENVIRONMENTAL IMPLICATIONS}

The Columbia River now represents a "regulated stream" (Ward and Stanford 1979) in the sense that man controls flow by an intricate system of dams and diversions. Many reservoirs in major U.S. rivers are operated so that flow downstream becomes more consistent, eliminating large spates or severe droughts. The relatively steady flow in such streams is one factor leading to a relatively stable shoreline zone and increased primary production. Other dams and reservoirs, particularly those used extensively for power production and irrigation, impart relatively immense and rapid changes in flow levels. This adversely impacts both primary production and secondary production of aquatic plants and animals in shoreline zones.

The Columbia River at Hanford experiences rapidly fluctuating water levels. Daily and weekly variations due to power production and flow regulation at an upstream dam are imposed upon seasonal changes from annual runoff patterns, as modified by operation of upstream storage reservoirs.

The faunal region most sensitive to water level fluctuations is the shoreline or eulittoral zone. Benthic fauna with limited mobility can be stranded by receding water and subject to entrapment, desiccation, oxygen and thermal stress, or predation. Changes in water level can also alter the physical nature of the river bottom and result in loss of shoreline macrovegetation (Hunt and Jones 1972). A number of potential environmental impacts from water fluctuations below hydroelectric dams, based largely on a literature survey, have been identified (e.g., Hildebrand 1980). Furthermore, water level changes in the littoral zone can be expected to impact fish populations indirectly (Estes 1972).

The most valued fish species affected by water level fluctuation in the Hanford Reach are fall chinook salmon (a sport, commercial, and Indian subsistent and ceremonial species) and smallmouth bass (a sport species). The chinook salmon is an obligatory riverine form that requires flowing water for existence. The smallmouth bass is not obligatory riverine, but can exist as we 11 in lentic environments such as lakes and ponds. Other species of fish inhabiting the Columbia River (Gray and Dauble 1977) may fit into either 
category. Generally, the native fish are riverine while the introduced forms are both riverine and lentic. Their welfare in the free-flowing Hanford Reach is related, in part, to the extent that critical life stages depend on shoreline zones for feeding and protection.

Two critical periods for chinook salmon in the Hanford Reach occur when eggs are intergravel during winter and when fry are emerging during spring. Considerable effort has been made to determine relationships between minimum low flows and salmonid reproduction success (Bauersfield 1978, Stillwell et a1. 1977, Witty and Thompson 1974). The drawdown of the Columbia River below Priest Rapids Dam on April 10 and 11, 1976, to $36,000 \mathrm{cfs}\left(1020 \mathrm{~m}^{3} / \mathrm{sec}\right)$ resulted in an estimated $k i l l$ of 834,000 chinook salmon fry still intergravel in redds (Bauersfeld 1978). River flows below $18,000 \mathrm{cfs}\left(510 \mathrm{~m}^{3} / \mathrm{sec}\right.$ ) on the Snake River above Lewiston, Idaho, also expose fall chinook salmon redds (Witty and Thompson 1974). In both cases, the losses occurred within legal flow guidelines established by the Federal Power Commission. However, low flows in most rivers supporting anadromous salmon in population in the Pacific Northwest are usually maintained above minimum permissable levels.

Stranding of chinook salmon fry on shores and gravel bars after emergence is not necessarily related to minimum flow levels, but to daily changes of lesser magnitude that often occur at frequent, repetitive intervals. Observations at Hanford confirm that young salmon are susceptible to stranding and related impacts from late March through July when these fish are present in inshore areas. During this period, young salmonids are also susceptible to impingement on intake screens of water diversions (Scriber et al. 1974; Page, Gray and Neitzel 1977; Page, Neitzel and Gray 1978). Impingement is also influenced by intake flow velocities and, hence, by the prevailing Columbia River water level.

The extent of young salmonid stranding may be related to different site features. For example, stranding on the Skagit River in northwestern Washington State is related to species, seasonal availability of fry, tributary inflow, time of day flows are reduced, sequence of peaking flow followed by low flow release, duration of low flow, and topography of the river channel (Thompson 1970; Phinney 1974). Such factors appear to be both 
site specific and generic (e.g., related to the Hanford area) as follows: 1) less fish are stranded if rapid decreases in water flow occur in daylight hours (fish escape more readily); 2) a high discharge prior to a reduction in flow increases the potential for fish stranding (by flooding inshore areas that fish enter); 3 ) a rapid flow reduction after a peak discharge causes the greatest problem (fish have less time to escape); 4) the lower the flow, the greater the stranding problem (more depressions and potholes in the river bottom entrap more fish); and 5) more fish are lost as the low-flow period lengthens (depression and potholes become warmed and drain, and trapped fish are exposed to predation).

It is difficult to quantify the true extent of juvenile fish loss from stranding due to water level fluctuations in the Hanford Reach. One factor is logistical--there are constraints on available funds, time, and manpower. A second factor is the variable rate and frequency of water level changes. Still another factor is rapid disappearance of entrapped fish. Observations demonstrate that only a fraction of the small fish estimated in pools before dewatering can be accounted for one day afterward. Some fish are removed by predators and scavengers. Others work into mud and gravel substrate before they die, or penetrate beneath larger cobblestones where they cannot be detected during walking surveys. Thus, estimates of number of salmonid fry lost during specific dewatering experiments in various northwest streams (Thompson 1970; Page 1976; Witty and Thompson 1974; Stilwell et al. 1977) are probably conservative.

The movement of adult smallmouth bass into our study sites in the spring for spawning, and their dispersion in late summer after spawning, indicates that the Hanford section of the Columbia River is important in sustaining local bass population levels. The full extent of this contribution is unknown. Other sites in the Hanford Reach, as well as locations above and below, may also be used by smallmouth bass for spawning. However, the Hanford Sloughs historically have been recognized by sport fishermen as gathering spots for smallmouth bass (Henderson and Foster 1956), and they may represent the most important spawning sites in the area. 
Annual spawning success of adult smalimouth bass at Hanford appears to be related to seasonal high or low flow and to the extent of water level fluctuations in spawning areas during the spring and summer (Montgomery, Fickeisen and Becker 1980). Poor spawning success in 1976 was related to cold water temperatures in slough areas, a result of high river flows. This may explain the extended residence time of smallmouth bass and delayed spawning. In addition, week iy and daily changes in river flow caused abrupt temperature changes at nesting locations. High flows entering the sloughs imparted cooler water, while low flows allowed the confined water to warm. The cycle was repeated as water levels fluctuated. Moreover, fry were vulnerable to entrapment and desiccation in flooded, usually grassy, shoreline areas.

Smallmouth bass spawning in 1977 appeared to be more successful than in 1976. The generally low river level allowed water in spawning areas to warm and stabilize. Thus, adult bass matured sexually and spawned on schedule. Subsequently, less severe inundation of slough areas apparently accounted for greater egg hatch and fry survival. The enclosed F-Area Slough, where no fluctuations in water level occurred during the spring, produced the largest number of schooling bass fry. Fry of White Bluff and Hanford sloughs were also more numerous than in 1976 and were less affected after hatching by abrupt changes in water level.

The extent to which fish species other than chinook salmon and smallmouth bass are affected by water level fluctuations is related to their use of shoreline zones for spawning and rearing young. Not all of these relationships are known or understood. Largemouth bass also spawn in the study sloughs, but are less abundant than smallmouth bass. Whitefish fry are vulnerable to water level changes and stranding, and apparent $7 y$ were stranded more than any other species during the low-flow experiment on April 10 and 11, 1976, (Page 1976). Our observations show that the young of many Columbia River fish inhabit shoreline zones for feeding and protection, and that they enter flooded, grassy areas during high flow periods. Most other fry species found stranded or isolated in pools during 1976 and 1977 consisted of "coarse fish" of little economic value, which generally exist in biological surplus. Such species include carp, bridgelip and largescale sucker, redside shiner, squawfish, chiselmouth, peamouth, threespine stickleback, sculpins and dace. 
Loss of benthic invertebrate fauna from water level fluctuations can be extensive. Particularly noticeable in dehydrated pools and depressions in the study areas were caddisfly and chironomid larvae, mayfly and dragonfly nymphs, and various water beetles. Crayfish were often entrapped or desiccated, but, like fish fry, the portion detected was probably a fraction of the actual loss. For example, few stranded crayfish were counted during the Apri1 10 and 11, 1976, low-flow experiment (Page 1976, this report). Two weeks prior to the test, only two crayfish appeared on the intake screens of the Hanford Generating Plant, but 59 dead crayfish appeared on these screens the week following (Page, Gray and Neitzel 1977).

Loss of benthic invertebrates is probably related to the sequence of water level fluctuations that expose shoreline zones. A period of sustained high flow is required for most invertebrates to colonize a previously exposed shoreline. A slow decline in flow permits some of the mobile invertebrates to accompany the receding water, while a rapid decline causes more stranding. In either case, substrate depressions such as pools and puddles provide temporary refuges that may become death traps. Space formerly occupied by lost organisms may be refilled with survivors from deeper water after flows increase, but total numbers of invertebrates in the ecosystem are temporarily reduced. Hence, missing forage organisms are not available to consumers at higher trophic levels. Effects of water drawdowns on aquatic invertebrates in riparian habitats are detailed in other publications (Fisher and LaVoy 1972; Kroger 1973; Brusven, MacPhee and Biggam 1974; Brusven and MacPhee 1976; Ward 1976; Brusven and Trichey 1978; Haber, Moore and Hicks 1978; Trotzky and Gregory 1974). In shorelines where water levels fluctuate irregularly, the main effect is usualiy a reduction of primary and secondary productivity.

The effects of water fluctuations on fish and invertebrate populations in the Hanford Reach of the Columbia River may never be fully quantified. Impacts on important fish species such as fall chinook salmon and smallmouth bass may be reflected at the adult population level because sensitive life stages of these species are affected directly. Thus, water level fluctuations can be crucial to their continued survival. Most other species of Columbia River fish, especially the arbitrary "coarse fish" species, apparently exist in 
abundance and replenish depleted areas rapidly. Loss of fish and invertebrates by water level fluctuations may be of little importance to overall ecosystem dynamics. 


\section{ACKNOWLEDGMENTS}

The reported observations and this publication were funded by the U.S. Department of Energy under Contract DE-AC06-76RLO 1830. Field research in 1976 and 1977 required the assistance and cooperation of many personne 1 in the Freshwater Sciences Section of PNL. The authors wish to acknowledge significant contributions provided by Dennis $W$. Crass and James M. Haynes, PNL, and by Jay Nelson, Bob Werberig, Allan Sherret and Sean Murphy, NORCUS appointees. Manuscript drafts were critically evaluated by Thomas L. Page, Duane A. Neitzel, and Colbert E. Cushing. Carolynn M. Novich provided editorial assistance. 


\section{LITERATURE CITED}

Battelle, Pacific Northwest Laboratories. 1976. Final Report on Aquatic Ecological Studies Conducted at the Hanford Generating Project. 1973-1974. WPPSS Columbia River Ecoloqy Studies Vol. 1. Prepared for United Engineers and Constructors for Washington Public Power Supply System by Battelle, Pacific Northwest Laboratories, Richland, Washington.

Bauersfeld, K. 1978. The Effect of Daily Flow Fluctuations on Spawning Fall Chinook in the Columbia River. Tech. Rept. No. 38, Washington State Department of Fisheries, 01ympia, Washington.

Becker, C. D., R. G. Genoway and J. A. Merri11. 1975. Resistance of a northwestern crayfish, Pacifastacus leniusculus (Dana) to elevated temperatures. Trans. Am. Fish. Soc. 104(2):374-387.

Brett, J. R. 1952. Temperature tolerance in young Pacific salmon, genus Oncorhynchus. J. Fish. Res. Bd. Canada 9:265-323.

Brusven, M. A., and C. MacPhee. 1976. The Effect of River Fluctuations Resulting from Hydroelectric Peaking on Selected Aquatic Invertebrates and Fish. Research Technical Completion Report, July 1971 - September 1975. Project A-035-IDA. Idaho Water Resources Research Institute, Univ. of Idaho, Moscow, Idaho.

Brusven, M. A., C. MacPhee and R. Biggam. 1974. "Effects of Water Fluctuations on Benthic Insects", In: Anatomy of a River, eds. Keith Bayha and Char les Koski, pp. 67-79. Pacific Northwest River Basins Commission, Vancouver, Washington.

Brusven, M. A., and E. F. Trihey. 1978. Interacting Effects of Minimum Flow and Fluctuating Shorelines on Benthic Stream Insects. Research Technical Completion Report, Project A-052-IDA. Idaho Water Resources Research Institute, Univ. of Idaho, Moscow, Idaho.

Carlander, K. D. 1977. Life History Data on Centrachid Fishes of the United States and Canada, Handbook of Freshwater Fishery Biology, Vol. Two. The Iowa State Univ. Press, Ames, Iowa.

Emig, J. W. 1966. "Smallmouth Bass." In: Inland Fisheries Management, ed. A. Calhoun, pp. 354-366. State of California, Department of Fish and Game, Sacramento, California.

Estes, R. D. 1972. Ecological Impact of Fluctuating Water Levels in Reservoirs. United States Bureau of Reclamation Report, REC-CRC-72-17, Washington, DC.

Fisher, S. G., and A. LaVoy. 1972. Differences in littoral fauna due to fluctuating water levels below a hydroelectric dam. J. Fish. Res. Bd. Canada 29(10):1472-1476. 
Gray, R. H., and D. D. Dauble. 1977. Checklist and relative abundance of fish species from the Hanford Reach of the Columbia River. Northwest Sci. 51(3):208-215.

Haber, D. F., B. Moore and W. Hicks. 1978. A Review of Impacts of Fluctuating Flows on the Lower Clearwater River and Recommendations for Future Studies. Contract No. DAC W68-78-M-2586. Idaho Water Resources Research Institute, University of Idaho, Moscow, Idaho.

Heman, M. L.. R. S. Campbel1 and L. C. Redmond. 1969. Manipulation of fish populations through reservoir drawdown. Trans. Am. Fish. Soc. 98(2):293-304.

Henderson, G., and R. F. Foster. 1956. Studies of smal1mouth bass (Micropterus dolomieui) in the Columbia River near Richland, Washington. Trans. Am. Fish. Soc. $36: 112-127$.

Hildebrand, S. G., ed. 1980. Analys is of Environmental Issues Related to Sma 11-Scale Hydroelectric Development. III. Water Level Fluctuation. ORNL/TM-7453, Oak Ridge Nationa 7 Laboratory, Oak Ridge, Tennessee.

Hunt, P. C., and J. W. Jones. 1972. The effect of water level fluctuations on littoral fauna. J. Fish. Biol. 4:385-394.

Kroger, R. L. 1973. Biological effects of fluctuating water levels in the Snake River Grand Teton National Park, Wyoming. Am. Midl. Natural. $89(2): 478-481$.

Montgomery, J. C., and D. H. Fickeisen. 1978. Spawning and Movements of Smallmouth Bass (Micropterus dolomieui) in the Mid-Columbia River. PNL-2785. Pac if ic Northwest Laboratory, Richland, Washington.

Montgomery, J. C., D. H. Fickeisen and C. D. Becker. 1980. Factors influencing smallmouth bass production in the Hanford Area, Columbia River. Northwest Sci. 54(4):296-305.

Page, T. L. 1976. Observations on Juvenile Salmon Stranding in the Columbia River, April 1976. Prepared for Washington Public Power Supply System by Battelle, Pacific Northwest Laboratories, Richand, Washington.

Page, T. L., D. A. Neitzel and R. H. Gray. 1978. "Comparative Fish Impingement at Adjacent Intakes." In: Proceedings of the Fourth National Workshop on Impingement and Entrainment, ed. L. J. Jensen, pp. 257-266. Ecological Analysts Communications, MeTrille, New York.

Page, T. L., R. H. Gray and D. A. Neitze1. 1977. Fish Impingement and Screen

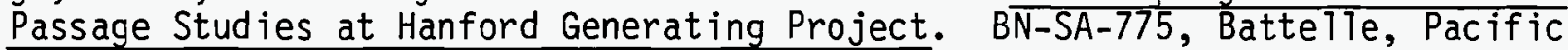
Northwest Laboratories, RichTand, Washington. 
Parametrics, Inc., D. Chapman and T. Welsh. 1979. Vernita Bar Spawning Survey 1978-79. Document No. 79-1221-36F, Grant County Public Utility District, Ephrata, Washington.

Phinney, Lloyd A. 1974. Further Observations on Juvenile Salmon Stranding in the Skagit River March 1973. State of Washington Department of Fisheries, Management and Research Division, Washington.

Robins, C. R. (Chairman), R. M. Bailey, C. E. Bond, J. R. Brooker, E. A. Lachner. R. M. Lea and W. B. Scott. 1980. A List of Common and Scientific Names of Fishes from the United States and Canada, 4th Ed. Special Pub T. No. 12, American Fish Society, Washington, DC.

Scott, W. B., and E. J. Crossman. 1973. Freshwater Fishes of Canada. Bu11. 184, Fish. Res. Bd. of Canada, Ottawa.

Schreiber, L. L., C. D. Becker, J. J. Fuquay and R. A. Chitwood. 1974. Intake system assessment for central Columbia River. J. Power Div., ASCE 100 (P02): :139-155.

Springer, J. T. 1977. Movement Patterns of Coyotes in South-central Washington as Determined by Radio Telemetry. PhD Thesis, Washington State University, Pul1man, Washington.

Stanford, J. A., and J. V. Ward. 1979. "Stream regulation in North America". In: The Ecology of Regulated Streams, eds. James V. Ward and Jack D. Stanford, pp. 215-236. Plenum Press, New York.

Stillwel1, F. P., J. K. Adkins, M. D. Evenson, R. D. Ewing and J. J. Martin. 1977. Determination of Salmonid Egg Mortality Resulting from Closure of Lost Creek Dam September 1, 1976 - Apri1 30, 1977. Information Report Series, Fisheries Number 77-9, Oregon Dept. Fish and Wild ife, Research Section, Corvallis, Oregon.

Tester, J. R., and D. B. Siniff. 1976. Vertebrate Behavior and Ecology. Progress Report for Period July 1, 1975 through June 30, 1976. CDO-1332123. Prepared for U.S. Energy Research and Development Administration by the University of Minnesota, Minneapolis, Minnesota

Thompson, J. S. 1970. The Effect of Water Flow Regulation at Gorge Dam on the Stranding of Salmon Fry in the Skagit River. Rept. No. 533, Washington State Department of Fisheries, 01ympia, Washington

Trotzky, H. M., and R. W. Gregory. 1974. The effects of water flow manipulation below a hydroelectric power dam on the bottom fauna of the Upper Kennebec River, Maine. Trans. Am. Fish. Soc. 103(2):318-324.

U.S. Army Corps of Engineers. 1977. Pacific Northwest Regional Pumped Storage Study. Informational Brochure No. 1. USACE, North Pac if ic Division, Port land, Oregon. 
Ward, J. V. 1976. "Effects of flow patterns below large dams on stream benthos: A review." In: Inflow Stream Needs, Vol. II, eds. John F. Orsborn and Charlena H. Allman, pp. 235-253. American Fisheries Society, Bethesda, Maryland.

Ward, J. V., and J. A. Stanford. 1979. The Ecology of Regulated Streams. Plenum Press, New York.

Witty, K., and K. Thompson. 1974. "Fish Stranding Surveys." In: Anatomy of a River, Keith Bayha and Charles Koski, pp. 113-120. Pacific Northwest River Basins Commission, Vancouver, Washington. 


\section{DISTRIBUTION}

No. of

Copies

OFFSITE

A. A. Churm

DOE Patent Division

9800 S. Cass Avenue

Argonne, II 60439

Dr. D. H. Hamilton

EV-34, GTN

U.S. Department of Energy

Washington, DC 20545

Dr. R. A. Lewis

EV-34, GTN

U.S. Department of Energy

Washington, DC 20545

David Grimes

EV-34, GTN

U.S. Department of Energy

Washington, DC 20545

He len McCammon

EV-34, GTN

U.S. Department of Energy

Washington, DC 20545

27 DOE Technical Information Center

Ross G. Antipa

Washington State Dept. of Fisheries

115 General Admin. Bldg.

Olympia, WA 98504

Doug Arndt

Port land District

U.S. Army Corps of Engineers

319 S.W. Pine

Portland, OR 97204

R. W. Brocksen

Environ. Assessment Department

Electric Power Research Institute

P. 0. Box 10412

Palo Alto, CA 94303
No. of

Copies

M. A. Brusven

Idaho Water Resources Res. Institute University of Idaho

Moscow, ID 83843

Ron Bush

Seattle District

U.S. Army Corps of Engineers

P.0. Box C-3755

Seatt Te, WA 98124

Ron Campbe 11

Regional Siting Team

Northwest Energy Systems Co.

P. 0. Box 1090

Kirkland, WA 98033

Rick D. Cardwe 11

Envirosphere Co.

$\mathrm{Rm} 715,10800 \mathrm{NE}$ 8th St.

Belevue, WA 98004

Bob Clubb

Puget Sound Power and Light

Puget Power Building

Bellevue, WA 98009

Charles C. Coutant

Environmental Sciences Division

Oak Ridge National Lab.

P.O. Box $X$

Oak Ridge, TN 37830

Mike B. De11

Grant Co. Public Utility District

P.0. Box 878

Ephrata, WA 98823

Greg Drais-PBE

Bonneville Power Administration

P. 0. Box 3621

Portland, OR 97208 
No. of

Copies

Wesley J. Ebe 1

National Marine Fisheries Services

2725 Montlake, Blvd.

Seattle, WA 98112

Tony Eldred

Wash. St. Dept. of Game

3860 Chelan Highway

Wenatchee, WA 98801

Michael W. Erho

Douglas Co. Public Utility District

1151 N. Main St.

E. Wenatchee, WA 98801

Duane H. Fickeisen

Rural Route

Cook, WA 98605

J. Roy Hamilton

Pacific Power \& Light Co.

Public Service Bldg.

Port land, OR 97204

Steve G. Hildebrand

Environmental Sciences Division

Oak Ridge National Lab.

P.0. Box $X$

Oak Ridge, TN 37830

B. D. Leman

Chelan Co. Public Utility District

P.0. Box 1231

Wenatchee, WA 98801

Edward M. Mains

Environmental Resources Branch

North Pacific Division

U.S. Army Corps of Engineers

P.0. Box 2870

Portland, OR 97209

James McColquin

Wash. St. Dept. of Game

658 West First

Kennewick, WA 99336
No. of

Copies

James E. Mudge

Wash. Public Power Supply System

P.0. Box 968

Richland, WA 99352

Roy E. Nakatani

Fisheries Research Institute

University of Washington

Seattle, WA 98105

Alan V. Nebeker

Corvallis Environmental Research

Lab, EPA

Western Fish Toxicology Station

1350 S.E. Goodnight Ave.

Corvallis, OR 97330

Karen Northrup

Seattle District

U.S. Army Corps of Engineers

P.0. Box C-3755

Seattle, WA 98124

Pacific Northwest River Basins Commission

Columbia River

P.0. Box 908

Vancouver, WA 98660

Donn L. Park

National Marine Fisheries Services

2725 Mont lake, Blvd.

Seattle, WA 98112

Lloyd Phinney

Wash. St. Dept. of Fisheries

115 General Admin. B1dg.

Olympia, WA 98504

Paul J. Rago

U.S. Fish and Wildlife Service c/o Great Lakes Fisheries Lab. 1451 Green Road, Rm. 105

Ann Arbor, MI 48105

Howard L. Raymond

National Marine Fisheries Services 2725 Mont lake, Blvd.

Seatt 1e, WA 98112 
No. of

Copies

Wende 11 E. Smith

Idaho Power Company

1914 N. Amber

Boise, ID 83706

Quent in J. Stober

Fisheries Research Institute

Univ. of Washington

Seatt 1e, WA 98105

Tom Voge 1

Bonneville Power Admin.

P. 0. Box 3621

Portland, OR 97208

Don Weitkamp

Parametrix, Inc.

13020 Northup Way, Suite 8

Bellevue, WA 98005

Tom Welsh

Idaho Coop. Fish Res. Unit

College of Forestry

University of Idaho

Moscow, ID 83843

Bil1 Zook

Wash. St. Dept. of Game

P.0. Box 1237

Ephrata, WA 98823
No. of

Copies

ONSITE

DOE Richland Operations Office

H. E. Ransom

57 Pacific Northwest Laboratory

W. J. Bair

C. D. Becker (20)

D. W. Crass

C. E. Cushing

D. D. Dauble

C. I. Gibson

K. E. Harding (4)

D. C. Klopfer

D. A. Neitzel (12)

C. M. Novich

T. L. Page

T. M. Poston

W. H. Rickard

J. A. Strand

W. L. Templeton

B. E. Vaughan

D. G. Watson

Publishing Coordination (2)

Technical Information (5) 